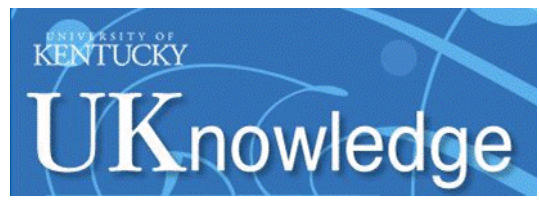

University of Kentucky

UKnowledge

Institute for the Study of Free Enterprise

Working Papers

Institute for the Study of Free Enterprise

2-2019

\title{
The Federal-Private Wage Differential: How Has It Evolved?
}

\section{Sun-ki Choi}

St. Lawrence University, choi@stlawu.edu

John Garen

University of Kentucky, john.garen@uky.edu

Follow this and additional works at: https://uknowledge.uky.edu/isfe_papers

Part of the Economics Commons

Right click to open a feedback form in a new tab to let us know how this document benefits you.

\section{Repository Citation}

Choi, Sun-ki and Garen, John, "The Federal-Private Wage Differential: How Has It Evolved?" (2019).

Institute for the Study of Free Enterprise Working Papers. 9.

https://uknowledge.uky.edu/isfe_papers/9

This Research Paper is brought to you for free and open access by the Institute for the Study of Free Enterprise at UKnowledge. It has been accepted for inclusion in Institute for the Study of Free Enterprise Working Papers by an authorized administrator of UKnowledge. For more information, please contact UKnowledge@lsv.uky.edu. 


\title{
The Federal-Private Wage Differential: How Has It Evolved
}

\section{Sun-Ki Choi John Garen}

February 2019

Institute for the Study of Free Enterprise

Working Paper 21

\author{
University of Kentucky \\ 244 Gatton College of Business and Economics \\ Lexington, KY 40506-0034 \\ http://isfe.uky.edu/
}

\section{Gatton College of




\title{
The Federal-Private Wage Differential: How Has It Evolved?
}

\author{
Sun-Ki CHOI* \\ St.Lawrence University \\ JOHN GAREN ${ }^{\dagger}$ \\ University of Kentucky
}

FEBRUARY 16, 2019

\begin{abstract}
Federal, state, and local budget issues in the aftermath of the Great Recession stimulated a revival of interest in government worker pay. In the paper, we study the evolution of the federal-private pay differential from 1995 to 2017 using Current Population Survey data, enabling us to examine the current pay gap and how it has changed over time. Wage regressions are estimated by year for federal and private sector workers and used to calculate the yearly federal-private wage differential. To deal with unobserved heterogeneity, we adopt control function methods. We also estimate of the probability of receiving employer-provided health insurance and a pension plan each year for each sector. The findings imply that the federal pay differential is invariably positive, fell during the 1990s, rose in the early 2000s until 2013, then tended to decrease. There is evidence that the differential is related to federal spending relative to GDP, but not to the business cycle. Federal workers consistently have higher probabilities of having employer-provided pension plans and health insurance.
\end{abstract}

Keywords: wage differential, public-private, federal wage system, compensation JEL Classification Codes: J24, J26, J31, J32, J33, J45

${ }^{*}$ Contact Information: Sun-Ki Choi, Department of Economics, St. Lawrence University, 204 Hepburn, 23 Romoda Dr., Canton, NY 13617; Email: schoi@stlawu.edu, Phone: (315) 229-1874

${ }^{\dagger}$ Contact Information: John Garen, 223P Gotton College of Business and Economics, University of Kentucky, Lexington, KY 40506; Email: jgaren@uky.edu

${ }^{\ddagger}$ For helpful comments, we thank William Hoyt, Carlos Lamarche, and session participants at the Southern Economic Association conference and the Association of Private Enterprise Education meetings. For support, Garen thanks the Institute for the Study of Free Enterprise and the BB\&T Program for the Study of Capitalism, both at the University of Kentucky. 


\section{Introduction}

There is long-standing interest in labor economics about the compensation of government workers relative to their private-sector counterparts. The modern, human capital/Mincerian wage equation approach to this topic was pioneered in a series of papers by Smith (1976a,b,1977). There has been recent revival of interest in the issue, with Congressional Budget Office (2012, 2017), Bradley (2012), and Biggs and Richwine (2011) examining the federal-private compensation differential, Gittleman and Pierce (2012), Munnell (2011), and Allegretto and Keefe (2010) studying state and local government pay, and Bewerunge and Rosen (2012) investigating all levels of government compensation. We suspect this increased attention is to the surge in federal deficits and the squeeze on state and local government budgets in the aftermath of the Great Recession. Presumably, any overcompensation of public employees presents potential for government cost savings.

Though the current wage and compensation difference of public and private employees is of interest, this paper produces and examines a time series of the pay differential between federal and private-sector employees. This enables us to determine not only the current pay differential but also if it has changed over time. We study the time period from 1995 to 2017. For wages and salaries, we use the CPS Merged Outgoing Rotation Group (CPS MORG). There are well documented differences in federal and private fringe benefits as well and we examine these using the March Current Population Survey (CPS). For this analysis, we estimate the probabilities that private sector and federal sector workers receive health insurance and pension benefits from their employers. 
We find that, over this time period, the federal-private wage differential is always positive but varies from a low of 3.4 percent to a high of 17.7 percent. This differential fell through the late 1990s, rose steadily in the 2000s until 2013, then tended to decrease. An analysis of these differentials suggest some evidence that they grow as federal spending as a share of GDP grows but, once this is accounted for, they are unrelated to the business cycle. Also, federal workers have much higher probabilities of receiving employer-sponsored pension plans and health insurance, though time patterns in these differentials are not as clear.

In our analysis of wages, we deal with unobserved heterogeneity by using control function methods. Naturally, systematic unobserved differences in the abilities of federal and private workers can bias estimates of the wage differentials. The control function approach we adopt allows ability to be two-dimensional rather than one-dimensional. This is consistent with a Roy model, where some workers' unobserved traits make them more suited to one sector and not another. One-dimensional ability is a special case that we test for and reject for many of the years in our data. One-dimensional unobserved ability may be dealt with by instrumental variable (IV) or fixed effects (FE) methods, but because this is frequently rejected in the data, we do not use these methods. Moreover, though the selectivity bias we find is statistically significant in many cases, its magnitude is very small and estimates are nearly identical to those from OLS.

The remainder of this paper proceeds as follows. Section 2.1 briefly reviews the past literature on public-private wage differentials and section 2.2 provides an overview of federal rules on compensation. Section 3 describes the main dataset, the CPS MORG, and presents summary statistics for the main variables. Section 4 presents the results from the OLS wage 
equations. The handling of the unobservables and the findings are discussed in Section 5. Section 6 examines how the probability of pension plan and health insurance coverage differ between federal and private workers. In Section 7, we examine how the time path of the federal-private wage differential depends on federal spending, the business cycle, and presidential administration. Lastly, Section 8 concludes.

\section{Background}

\subsection{Past Literature ${ }^{1}$}

Wage differentials between public and private sector employees have been well documented starting with Smith's seminal series of papers (1976a, 1976b, 1977). Smith (1976a) found that in 1960, federal workers were paid more than comparable private sector workers and this wage advantage continued in 1970. This difference implied that the earlier reforms made in the federal pay system did not bring federal pay in line with the private sector. Smith (1977) also found that the government wage differential varied by level of governmentfederal, state, or local - and by gender. Moulton (1990) revisited public-private wage differentials by taking into account better occupational controls and differences in local labor market conditions. He found that doing so reduced that magnitude, but did not eliminate, the federal wage gap.

A number of papers consider the growing skill differential in the private sector, as well as the responsiveness of government pay to market conditions, and how they may affect the

\footnotetext{
${ }^{1} \mathrm{~A}$ more extensive review is in Choi (2016).
} 
public-private wage gap. Katz and Krueger (1991) note that during the 1980s growth in the private-sector skill differential, there was not much change in federal wages in this regard. They indicate, though, that state and local government wages seemed more responsive to local economic conditions. Freeman (1987) also considers the sensitivity of government pay to economic conditions. He finds that that state and local government wages and employment respond to their respective government budgets, but with no clear patterns regarding federal workers. Borjas (2003) examines the skill differential and wage dispersion from 1960 to 2000 in the public and private sectors. The greater growth of wages at higher skill levels in the private sector is verified and he shows that this growth was not matched in the public sector, resulting in relatively less wage dispersion. Borjas (2003) indicates that this has made it more difficult to recruit high skilled workers into government. ${ }^{2}$

Public-private wage differentials also have generated recent research efforts. Bewerunge and Rosen (2012) examine federal, state, and local compensation differentials for 2004 and 2006 with data from the Health and Retirement Survey. They find a substantial wage premium for federal worker but very little differences for state and local workers. However, workers at all levels of government attain more fringe benefit compensation relative to their private-sector counterparts. Biggs and Richwine (2011) and Congressional Budget Office $(2012,2017)$ investigate wage and fringe benefit differentials between federal and private workers. Biggs and Richwine (2011) consider the 2006 to 2010 time period, while the first Congressional Budget Office study examines 2005 to 2010 and the second considers 2011 to 2015. Each generally finds a positive federal wage premium, though it is much smaller

\footnotetext{
${ }^{2}$ See Borjas (1980) for his work on political influences on federal wages.
} 
(or even negative) at very high levels of education. Also, federal fringe benefits are higher for federal workers, though this advantage is less for the highly educated workers. Bradley (2012) summarizes some of this recent work as well as noting methodological issues.

An important issue in this literature is the role of unobserved productivity. For example, suppose federal workers are better on unmeasured dimensions and earn higher compensation as a result. This generates an ability bias, where the positive federal pay gap may, in part, reflect higher ability rather than a true pay premium. Some authors have utilized fixedeffect estimation to deal with this issue. Krueger (1988) does so with two data sets. One is Current Population Survey (CPS) matched data from the mid- to late-1970s. The other is CPS supplements on displaced workers from the mid-1980s. The former data show a small and insignificant effect of federal employment with the fixed effects estimator, compared to a large, positive and significant effect in the cross-sectional analysis. The latter show little difference between estimation methods: a 10.7 percent federal wage premium with fixed effects and a 12.6 percent gap with OLS. Biggs and Richwine (2011) find a 9 percent federal wage gap from a sample of individuals from 2004 to 2008 in the Survey of Income and Program Participation. This compares to their OLS estimate of a 14 percent pay gap using CPS data.

Gyourko and Tracy (1988) deal with unobservables via control function methods. Using data from the 1977 CPS, they estimate the union-nonunion wage differential for the private and public sectors and the government wage differential for union and nonunion workers. They find a substantial wage differential for federal workers, but quite small differentials for state and local government employees. Interestingly, they find positive selection for private, 
nonunion workers and negative selection for public, union workers. This suggests that the ability bias may go in direction of underestimating the government wage differential. Also, their approach enables unobservables to affect wages in the different sectors in different ways, i.e., that ability may be multidimensional where someone may good in one sector but not in another. This is an issue that we examine in detail below. ${ }^{3}$

Other work has investigated public-private wage differentials in other countries. Several recent studies in European Union (EU) countries find positive pay differentials in favor of the public sector that are generally higher for women, for workers at the low end of the wage distribution, and in selected sectors. They also find notable differences across EU countries: Greece, Ireland, Italy, Portugal and Spain exhibited higher public sector premia than other countries. See Bargain and Melly (2008), Giordano, et. al. (2011), and Castro, et. al. (2013).

Other recent studies have focused solely on state and local government workers. These include Munnell et. al. (2011), Allegretto and Keefe (2010), and Gittleman and Pierce (2012). As with other related studies, they find no consistent wage differential between state or local government workers and the private sector. However, both groups of government workers are paid more in fringe benefits that similar private sector workers.

\subsection{Federal Rules on Compensation}

The private sector and federal government are potential competitors as employers in the labor market. In light of this, the federal government has devised compensation rules

\footnotetext{
${ }^{3}$ Van der Gaag and Vijverberg (1988) apply similar methods in their analysis of public and private wages in the Ivory Coast.
} 
in order to pay comparably to the private sector with both its basic pay system and its adoption of special rates. ${ }^{4}$ Here, we give an overview of those systems. According to U.S. Office of Personnel Management (OPM), the basic pay rules are also divided into two parts, General Schedule (GS) and the Federal Wage System (FWS). The GS classification and pay system covers the majority of the civilian white-collar federal employees in professional, technical, administrative, and clerical positions. The GS has 15 grades from GS-1 (lowest) to GS-15 (highest). Each grade is classified by job based on the responsibility, level of difficulty, and qualifications required. Each grade has 10 within-grade steps that are each worth approximately a 3 percent increase in the wage. The FWS was established for Federal blue-collar workers comparable to prevailing private sector rates in each local wage area. The FWS covers Federal trade, craft, and laboring employees. There are two basic principles for FWS: 1) wages are set according to local prevailing rates, and 2) there will be equal pay for equal work and pay distinctions in keeping with work distinctions. For each wage area, OPM identifies a lead agency that is responsible for conducting wage surveys, analyzing data, and issuing wage schedules under the two principals above. Employees are paid the full prevailing rate at step 2 in each grade. The highest step in FWS, step 5, the wage of employees is 12 percent above the prevailing rate of pay.

OPM establishes a higher rate of basic pay for a group or category of GS positions in one or more geographic areas to address existing or likely significant handicaps in recruiting or retaining well-qualified employees. The special rates address staffing problems caused by sig-

\footnotetext{
${ }^{4} \mathrm{~A}$ special rate is higher rate of basic pay for a group or category of General Schedule (GS) positions in one or more geographic areas to address existing or likely significant handicaps in recruiting or retaining well-qualified employees.
} 
nificantly higher non-federal pay rates than those payable by the federal government within the area, location, or occupational group involved. This includes the remoteness of the area or location involved, the undesirability of the working conditions or nature of the work involved, or any other circumstances OPM considers appropriate. Most of GS employees are entitled to locality pay, which is a geographic-based percentage rate that reflects pay levels for non-federal workers in certain geographic areas as determined by surveys conducted by the U.S. Bureau of Labor Statistics (BLS). There are currently 34 locality pay areas, which cover the lower 48 States and Washington D.C., plus Alaska, Hawaii, and the U.S. territories and possessions. For extraordinarily difficult living conditions and undesirable working conditions, the federal government pays both a cost-of-living allowance (COLA) and a post differential. A post differential means an addition to basic pay that is payable in selected non-foreign areas. A post differential is a recruitment incentive based on conditions of the environment in the non-foreign area that differ significantly from conditions in the U.S. as a whole. However, post differentials plus the COLA cannot exceed 25 percent of basic pay. These are reflected in our data on compensation and our examination of federal pay relative to private pay.

In addition, there is an overall COLA that raises basic rates of pay for each pay grade. The amount of this COLA is based on the Employment Cost Index. However, the President may alter or eliminate this pay increase due to unfavorable economic conditions. In fact, for 2011, 2012, and 2013, this COLA was set to zero. This does not mean, however, that federal pay raises during this period were zero. Federal employees may still obtain raises through moving up in steps or grades, as well as through changes in the area-based or other 
adjustments noted above.

\section{Basic Data}

Our primary data source is the Current Population Survey Merged Outgoing Rotation Group (CPS MORG) from the National Bureau of Economic Research (NBER) between 1995 and 2017. In recent years, each monthly CPS has included about 140,000 individuals living in approximately 70,000 households. Using the MORG data instead of the March CPS yields much larger number of observations because the MORG data is monthly. Each month's observations for a given year naturally form the pool of observations we use for that year. From the earnings and hours questions, we compute average hourly earnings and express in inflation-adjusted 2012 dollars. The usual demographic variables are utilized, as well as the sector of employment: private, federal government, or other government. We limit our sample to those who worked at least 35 hours per week and are age 18 to 70 .

Table 1 summarizes the mean wages of private workers and public sector workers from 1995 to 2017. Separate columns are presented for private sector workers, along with federal, state, and local government workers, with the latter two categories shown for informational purposes only. The focus of this paper is the federal-private differential. Figure 1 shows the unadjusted federal-private ratio over time. The ratio of average federal to average private sector wages is over 30 percent in each year and is over 40 percent in some years. This ratio fell during the initial years of our sample time frame, then increased over time.

We also examine coverage of workers by employer-provided health insurance and a pension plan. We rely on the annual March supplement of the CPS for this analysis since data 
on these variables are only available then. Table 2 and Figure 2 show the percent of workers covered by employer-based health insurance and pension benefits for the federal and private sectors. In each year, federal worker coverage exceeds that of the private sector for both of these fringe benefits. On average over this period, federal employees have an 12.3 percent higher coverage rate for health insurance (87.1 percent compared to 74.8 percent) and 32.3 percent higher for pension plan coverage (76 percent relative to 43.7 percent).

Table 3 present the summary statistics of variables that are included in our multivariate analysis. All wages in the data are expressed in 2012 dollars. In the entire sample period, 3.2 percent of individuals were working in the federal government. On average, these workers had more schooling, were slightly older, more likely to be unionized, more likely to be black, about equally likely to be female, and more heavily in managerial, professional, and administrative support occupations. Also shown are variables for urban-rural location, regions, and the 34 locality areas that the federal government offers locality wage differentials. Each of these are control variables in our empirical analysis.

Table 4 summarizes mean values of key variables from the CPS MORG data for both sectors over time. The average schooling level has increased in the federal and private sectors by about the same amount, as has average age. Percent female in the two sectors changed little over this time period. We also show the trends in the four occupational groups that comprise roughly 90 percent of federal workers - management, professional, service, and administrative support. The extent of managerial workers varied somewhat over time - falling then rising - among federal workers and rose slightly in the private sector. The percent of professionals rose in both sectors, as did the use of service workers. For 
administrative support personnel, the percent of the federal workforce in these occupations fell over time while it changed little in the private sector.

\section{Baseline OLS Estimation}

This section presents OLS estimation of the federal-private wage differential as a baseline for comparison to estimates that deal with unobserved heterogeneity. We estimate two separate equations, year-by-year; one for federal workers only and one for all private sector workers from 1995 to 2017. The equations that we use to estimate the OLS models are below. Here, the dummy variable $d_{i t}$ equals 1 if the worker is employed in the federal sector and 0 otherwise:

$$
\begin{aligned}
& \ln \left(Y_{i t}^{f}\right)=\beta_{0 t}^{f}+\beta_{i t}^{f} X_{i t}+\epsilon_{i t}^{f} \quad \text { if } \quad d_{i t}=1, \text { where } t=1995, \cdots, 2017 \\
& \ln \left(Y_{i t}^{p}\right)=\beta_{0 t}^{p}+\beta_{i t}^{p} X_{i t}+\epsilon_{i t}^{p} \quad \text { if } \quad d_{i t}=0, \text { where } t=1995, \cdots, 2017
\end{aligned}
$$

The variable $Y_{i t}$ is average hourly earnings for workers. The term $X_{i t}$ is a vector of individual characteristics and demographics including schooling, experience, gender, union status, race, MSA, region, occupation, and locality, and $\epsilon_{i t}$ is the disturbance term. Their summary statistics are as shown in Table 3 noted above. After obtaining estimated coefficients, the predicted federal-private wage differential is computed, evaluated at sample means.

Table 5 and Figure 3 summarize the estimated wage gap between two sectors. Calculating the wage differentials, year by year, using two separate equations from each sector, we find 
that federal government workers received between 3.4 percent and 17.7 percent more than their counterparts in private sector. Each of these differentials is statistically significant, except the lowest value which occurred in 1999. These findings suggest that the federal pay differential is invariably positive and, as can be seen, it fell during the 1990s, began to rise in the early 2000s, and generally continued to rise until 2013. Then it began to decrease to the end of the sample period.

Additional OLS wage regressions are estimated by year and separately for federal and private sector workers with only the four major occupation groups which dominate federal employment: management occupations; professional occupations; service occupations; and administrative support occupations. By focusing on this narrower set of white collar occupations, the sample is more comparable to the federal work force thus we may remove a good deal of unobserved heterogeneity from the estimates and provide a simple robustness check on the previous findings. Table 6 and Figure 4 present the computed federal wage differentials from this analysis. Overall time pattern of the differentials are quite similar to the previous case. However, these federal wage premia are more stable and tend to be slightly higher, varying between 8.2 and 16.9 percent. Note that the wage differentials estimated with this subsample or the entire sample above are in keeping with the magnitude of estimates found in the literature.

\section{$5 \quad$ Dealing with Unobservables}

The OLS model assumes that the 'public' variable is uncorrelated with disturbance term, implying that sectoral differences in unobserved characteristics do not affect the estimated 
wage differential. Here, we relax this assumption.

Let

$$
\begin{aligned}
& \ln \left(Y_{i t}^{f}\right)=\beta_{0 t}^{f}+\beta_{i t}^{f} X_{i t}+\phi_{i}+\theta_{i}^{f}+\epsilon_{i t}^{f} \quad \text { if } \quad d_{i t}=1 \\
& \ln \left(Y_{i t}^{p}\right)=\beta_{0 t}^{p}+\beta_{i t}^{p} X_{i t}+\phi_{i}+\theta_{i}^{p}+\epsilon_{i t}^{p} \quad \text { if } \quad d_{i t}=0
\end{aligned}
$$

where $\phi_{i}$ indicates the worker's absolute advantage in both the federal and private sectors, reflecting 'ability' such that a worker with a higher $\phi_{i}$ can earn a higher wage in both sectors. This is the usual person-specific fixed effect. We generalize this by including the terms $\theta^{f}$ and $\theta^{p}$, which are relative/comparative advantages indicating how well-matched an individual is to each sector. These are as in a Roy model. For example, a person can be well-suited to government work and not for the private sector, implying a large $\theta^{f}$ and a low $\theta^{p}$. Naturally, other cases are possible. If $\theta^{f}=\theta^{p}$ then this collapses to the special case of absolute advantage with only $\phi_{i}$. Note that the formulation of (2) and (3) allows 'abillty' to be two-dimensional rather than uni-dimensional. The $\epsilon_{i t}^{j}$ terms are white noise for each sector. These equations can be re-written as

$$
\begin{aligned}
& \ln \left(Y_{i t}^{f}\right)=\beta_{0 t}^{f}+\beta_{i t}^{f} X_{i t}+\epsilon_{1} \quad \text { if } \quad d_{i t}=1 \\
& \ln \left(Y_{i t}^{p}\right)=\beta_{0 t}^{p}+\beta_{i t}^{p} X_{i t}+\epsilon_{0} \quad \text { if } \quad d_{i t}=0
\end{aligned}
$$

where $\epsilon_{1}=\phi_{i}+\theta_{i}^{f}+\epsilon_{i t}^{f}$ and $\epsilon_{0}=\phi_{i}+\theta_{i}^{p}+\epsilon_{i t}^{p}$. A common way to deal a model like this with two dimensional unobservables is use of the Heckman-Lee method. Other methods such as instrumental variable (IV) and fixed effect (FE) models deal only with unidimen- 
sional ability. As shown below, using a control function approach, we can test whether the unobservable ability is one-dimensional or two-dimensional. To do so, we start with original Heckman-Lee assumption of joint normality. We later relax this assumption in our robustness checks.

The probability of a workers choosing the federal sector depends on the wage differential s/he obtains and exogenous factors such as the ease finding federal relative to private employment. Let the latter factor be represented by the vector $Z_{i}$. Then the probability of $d_{i t}=1$ is :

$$
\operatorname{Pr}\left(d_{i}=1\right)=X_{i} \delta+Z_{i} \gamma+\alpha \phi_{i}+\tau\left(\theta_{i}^{f}-\theta_{i}^{p}\right)+u_{i}
$$

Equation (6) can be written as

$$
\begin{gathered}
d_{i}=V_{i} \psi+\epsilon_{2} \\
d_{i}= \begin{cases}1 & \text { if } \epsilon_{2}>-V_{i} \psi \\
0 & \text { if } \epsilon_{2} \leq-V_{i} \psi\end{cases}
\end{gathered}
$$

where $\epsilon_{2}=\alpha \phi_{i}+\tau\left(\theta_{i}^{f}-\theta_{i}^{p}\right)$ and $V_{i}=f\left(X_{i}, Z_{i}\right)$. Note that equation (6) estimates the probability of being a federal government employee, thus we expect the term $\tau$ to be positive. That is, the better the match to federal employment, $\left(\theta_{i}^{f}-\theta_{i}^{p}\right)$, the more likely the person is a federal worker. The expectation of the disturbance terms for federal workers and private sector workers from equations (4) and (5) are

$$
E\left(\epsilon_{1} \mid d_{i}=1\right)=E\left(\epsilon_{1} \mid \epsilon_{2}>-V_{i} \psi\right)=\frac{\sigma_{12}}{\sigma_{2}}\left[\frac{f\left(V_{i} \psi\right)}{1-F\left(V_{i} \psi\right)}\right]
$$




$$
E\left(\epsilon_{0} \mid d_{i}=0\right)=E\left(\epsilon_{0} \mid \epsilon_{2} \leq-V_{i} \psi\right)=\frac{\sigma_{02}}{\sigma_{2}}\left[\frac{-f\left(V_{i} \psi\right)}{1-F\left(V_{i} \psi\right)}\right]
$$

where $\sigma_{12}$ is the covariance of $\epsilon_{1}$ and $\epsilon_{2}$ and $\sigma_{02}$ is the covariance of $\epsilon_{0}$ and $\epsilon_{2}, f$ is the standard normal density function and $F$ is the cumulative normal density function. It is these two expression that are the control function, or selection, variables.

Note that

$$
\begin{aligned}
\sigma_{12} & =\operatorname{Cov}\left(\epsilon_{1}, \epsilon_{2}\right) \\
& =\operatorname{Cov}\left(\phi_{i}+\theta_{i}^{f}+\epsilon_{i}^{f}, \alpha \phi_{i}+\tau\left(\theta_{i}^{f}-\theta_{i}^{p}\right)+u_{i}\right) \\
& =\alpha \sigma_{\phi}^{2}+\tau\left(\sigma_{f}^{2}-\sigma_{f p}\right)
\end{aligned}
$$

and

$$
\begin{aligned}
\sigma_{02} & =\operatorname{Cov}\left(\epsilon_{0}, \epsilon_{2}\right) \\
& =\operatorname{Cov}\left(\phi_{i}+\theta_{i}^{p}+\epsilon_{i}^{p}, \alpha \phi_{i}+\tau\left(\theta_{i}^{f}-\theta_{i}^{p}\right)+u_{i}\right) \\
& =\alpha \sigma_{\phi}^{2}+\tau\left(\sigma_{f p}-\sigma_{p}^{2}\right)
\end{aligned}
$$

where $\sigma_{f p}$ is covariance between $\theta^{f}$ and $\theta^{p}, \sigma_{f}^{2}$ and $\sigma_{p}^{2}$ are the variances of $\theta^{f}$ and $\theta^{p}$, respectively. ${ }^{5}$

If there is only absolute advantage, $\phi_{i} \not \equiv 0$ and $\theta_{i}^{f} \equiv \theta_{i}^{p} \equiv 0$, then from equation (10) and (11) :

$$
\begin{gathered}
\sigma_{12}=\alpha \sigma_{\phi}^{2} \\
\sigma_{02}=\alpha \sigma_{\phi}^{2}
\end{gathered}
$$

${ }^{5}$ The formulations in (10) and (11) assumes that $\phi$ is uncorrelated with the two match parameters, $\theta^{f}$ and $\theta^{p}$. Dropping this assumption changes little in our discussion. 
In this case, we have a standard one-diminsional, fixed-effect that can be dealt with via IV or FE estimation. In the Heckman-Lee framework, the coefficients on the selectivity variables are identical. If higher ability employees are more likely to be federal government worker $(\alpha>0)$, , then $\sigma_{02}=\sigma_{12}>0$. On the contrary, if higher ability employees are more likely to be private sector worker $(\alpha<0)$, then $\sigma_{02}=\sigma_{12}<0$.

With both absolute advantage and comparative advantages, $\phi_{i} \not \equiv 0$ and $\theta_{i}^{f} \not \equiv 0 \not \equiv \theta_{i}^{p}$, then depending on the size of each variance and covariance, $\sigma_{12}$ and $\sigma_{02}$ can be either sign. Positive values of $\sigma_{f}^{2}, \sigma_{p}^{2}$, and $\tau$ tend to make $\sigma_{12}>0$ and $\sigma_{02}<0$, though the other terms in (10) and (11) can generate different outcomes. The nature of the cross-equation correlation is readily tested with the Heckman-Lee methodology; it is a test of the equality of the coefficients on the two selectivity terms. ${ }^{6}$

To estimate the wage equations, we follow the standard Heckman-Lee procedure. We first estimate (7) with probit. For the vector of $Z_{i}$ variables, we use variables intended to capture the ease of finding private sector jobs relative to federal jobs in each worker's location. To control for business cycle factors that may affect this relative availability, we include the worker's state unemployment rate, the state real GDP growth rate, and the state employment growth rate. We also include the ratio of federal government workers to all employees in the state.

The wage equations we estimate can be written as:

$$
\ln \left(Y_{i t}^{f}\right)=\beta_{0 t}^{f}+\beta_{i t}^{f} X_{i t}+\frac{\sigma_{12}}{\sigma_{2}}\left[\frac{f\left(V_{i} \psi\right)}{1-F\left(V_{i} \psi\right)}\right]+\nu_{1} \quad \text { if } \quad d_{i t}=1
$$

\footnotetext{
${ }^{6}$ See Garen (1987) for a closely related discussion
} 


$$
\ln \left(Y_{i t}^{p}\right)=\beta_{0 t}^{p}+\beta_{i t}^{p} X_{i t}+\frac{\sigma_{02}}{\sigma_{2}}\left[\frac{-f\left(V_{i} \psi\right)}{1-F\left(V_{i} \psi\right)}\right]+\nu_{0} \quad \text { if } \quad d_{i t}=0
$$

where estimated values of the selectivity terms from the probit are substituted in above and $\nu_{1}$ and $\nu_{0}$ are the applicable disturbance terms. Here, we can see that this formulation enables a simple test of whether the Roy model is appropriate relative to a unidimensional ability model by testing the equality of the coefficients on the two selectivity term. If they are equal, then IV or FE estimation also may be applied. If they are not equal, then the latter two methods are not appropriate.

Table 7 and Table 8 show the coefficients on the two selectivity coefficients for each year, with the former table for entire sample and the latter for the subsample of four occupations. In Table 7, the coefficients for the private sector are consistently positive and significant. However, the coefficients for the federal sector workers are unstable and tend to be insignificant. The final column of Table 7 shows the t-statistics for the tests of equality of the coefficients. For nearly half of the years, we reject the hypothesis of equal coefficients. With a sample of only four occupations in Table 8, the pattern is similar to that in Table 7. In most cases, the coefficient for the private sector is positive and larger than that for the federal sector. For much of the sample period, the message is that the selectivity coefficients differ.

As is well known, the Heckman-Lee procedure rests on strong functional form assumptions. Thus, we proceeded with a more general control function approach and estimated a variety of models with many functional forms to determine the robustness of our results. ${ }^{7}$

\footnotetext{
${ }^{7}$ These procedures are in line with the guidance of Imbens and Wooldridge (2007).
} 
In particular, we estimated equation (7) that determines the worker's sector by linear probability and logit, as well as by probit. From each of these, we formed an estimate of $\mathrm{E}\left(\epsilon_{2 i}\right.$ $\left.\mid d_{i}\right)$. These were entered linearly, as quadratics, and as cubics in each wage equation. The findings are consistent with the above. There tends to be a positive and significant association of private sector wages and $\mathrm{E}\left(\epsilon_{2 i} \mid d_{i}=0\right)$. The association of federal sector wages and $\mathrm{E}\left(\epsilon_{2 i} \mid d_{i}=1\right)$ is unstable and generally not statistically significant. Tests of equality of the two effects on wages are mostly rejected. Moreover, when we calculate the federal-private wage differential using estimates with the various control functions, we find nearly identical results. Note that we frequently reject the one-dimensional model of ability. Because IV and FE estimation methods assume one-dimensional ability, it is not generally appropriate to use these methods and we pursue these alternatives no further. Additionally, as described below, we find that unobserved heterogeneity has little effect on the magnitude of the wage differentials.

The federal-private wage differential is calculated with the Heckman-Lee estimation and the results shown in Table 9 and Table 10. The former table is for the entire sample and the latter for the subsample of four occupation groups. The findings are nearly identical to those of OLS. Figure 5 plots the coefficients from Table 9 against the coefficients for the corresponding OLS wage equation of Table 5. Visually, they nearly overlay one another. The wage gap from Heckman-Lee model is at most 1.3 percent larger and is, at minimum, 0.8 percent smaller than that from OLS.

Regarding the four occupation subsample, Figure 6 plots the coefficients of Table 10 against the corresponding OLS coefficients from Table 6. Again, the plots are nearly iden- 
tical. Therefore, though selectivity bias generally is statistically significant, especially for private sector wages, its economic magnitude is so small as to make little difference in the wage differential computation.

Moreover, this indicates that our conclusions from the OLS analysis above continue to hold: the federal wage differential has been positive throughout this period; it fell in the late 1990s and rose fairly steadily though the 2000s until 2013 and then decreased to the end of the sample period; the subsample of four occupations suggests a larger differential in the 1990s with a smaller decline, but quite close to the differential from the entire sample for the later part of the period; the federal-private wage differential during this period was not lower than 3.4 percent and as high as 17.7 percent.

\section{$6 \quad$ Fringe Benefit Analysis}

Fringe benefits are often a large share of compensation so it is important to compare fringe benefit provision between the federal and private sectors. From the March CPS, the variables available are whether or not the worker has an employer-provided health insurance plan and an employer-sponsored retirement plan. Thus, we estimate the effect of federal sector employment on the provision of each of these, holding constant a host of covariates. In particular, we estimate the probability of receipt of each of these fringe benefits by probit as:

$$
P\left(Y_{i t}=1\right)=\Phi\left(X_{i t}^{\prime} \rho+d_{i t} \lambda\right)
$$


where $i$ indexes the individual, and $t$ indexes time. In this estimation, $Y_{i t}$ is a dummy variable indicating whether the worker has a health insurance plan or a retirement pension plan from his/her current employer, $\Phi(\cdot)$ is the cumulative distribution function for the standard normal. The vector of observable characteristics $X_{i t}$ and $d_{i t}$ are the same as in the OLS wage equation model. We run separate probit equations by year for health insurance and pension plan provision.

Table 11 shows the marginal effects of federal sector employment on the probability of obtaining each fringe benefit. Federal government workers enjoy a much higher probability of receiving an employer-provided retirement pension. This higher probability ranges from 13.4 to 29.6 percent, depending on the year. It decreased until the early 2000s, but then rose albeit is a somewhat irregular way. Figure 7 shows the plot of these differentials over time. The second column in Table 11 shows the findings is for employer-provided health insurance. The results for health insurance are less dramatic than for pensions. Federal workers generally have a higher probability of receiving health insurance, though by how much varies from year to year. It is as small as -4 percent and as large as nearly 11 percent. These effects are plotted in Figure 8 and show the somewhat irregular pattern just noted. This analysis reinforces earlier findings in the literature that federal workers are compensated with greater fringe benefits.

\section{Analyzing the Time Path of Wage Differentials}

In this section, we examine the relationship between the yearly estimated federal-private wage differential and national-level economic and political variables. To capture effect of the 
business cycle, we use the unemployment rate of 25 to 54 year olds. We also use the federal spending to GDP ratio. This variable may reflect both economic and political influences. Federal spending tends to rise as the business cycle worsens, so it may partially capture business cycle effects. Higher federal spending may also reflect a political environment more favorable to larger government and, naturally, more federal spending may enable higher federal pay. We also use a dummy variable for each presidential administration; Clinton, Bush, Obama, and Trump. These are utilized as explanatory variables to explain the time variation in the federal-private wage differential. The findings are presented in Table 12. For the first two columns, we use only the unemployment rate variable and the ratio of federal spending to GDP as covariates. Regarding the dependent variable, we use the wage differential from the sample of all workers in the first column and that from the subsample of four occupations in the second sample. ${ }^{8}$ These are as reported in Tables 9 and 10, respectively. For the first column, we find a positive and significant effect of federal spending on the federal wage differential. For all workers, an additional 1 percent of federal spending to GDP is associated with a 1.7 percent higher federal wage differential.

The unemployment rate variable has a negative though insignificant effect in the first column and positive and insignificant in the second column. One might expect a positive effect since a higher unemployment indicates a slack private labor market and some of the previous literature suggested a widening gap between federal and private wages. However, part of this effect may be captured in the federal spending variable since federal spending typically rises with the unemployment rate.

\footnotetext{
${ }^{8}$ Because the wage differentials are estimated, we correct for any potential problem with standard errors by using Huber/White robust standard errors.
} 
In the third and fourth columns of Table 12, we include dummy variables for each presidential administration, with the Clinton administration the omitted category. In the third column, the Bush and Obama administration dummies are both positive, with the former larger than the latter. The Trump administration dummy is negative. Only the Bush administration dummy is significant, though. Regarding the fourth column, the Bush and Obama administration coefficients are both quite small and insignificant, with the former positive and the latter negative. The Trump administration coefficient is negative and significant. Note, though, that these coefficients are reflective of the time pattern of the estimated wage differentials: for the entire sample, the differential fell, then rose throughout the Bush and Obama years and fell again during the Trump years, while for the subsample, the rise was mostly during the Bush years. Additionally, these are effects holding constant federal spending and the unemployment rate which changed substantial across presidential administrations. Regarding those effects, we find a positive effect of the ratio of federal spending to GDP in both columns, though it reaches significance only in the third column. The coefficients on the unemployment rate variable are negative and statistically insignificant.

\section{Conclusion}

Our empirical analysis of the federal wage differential from 1995 to 2017 reaches several robust conclusions. The differential has been positive throughout this period. It fell in the late 1990s and rose fairly steadily though the 2000s until 2013, and then tended to decrease to the end of the sample period. Our preferred estimate indicate it varied between 3.4 percent 
and 17.7 percent. A similar pattern emerges when examining only the four occupations that comprise most of the federal workforce. Results after correction for unobserved heterogeneity with use of control function methods are nearly identical to those from OLS. Additionally, the probabilities of federal workers having a pension plan and employer-sponsored health insurance are persistently higher than for private-sector workers.

Finally, we examine factors that affect the wage differential over time. Among economic indices, the federal spending to GDP ratio tends to be positively related to the wage gap. Once this is accounted for, the effect of the business cycle, as measured by the unemployment rate, has little effect. Holding constant the above two factors, the federal pay differential was higher under Bush and Obama administrations and lower under the Trump administration relative to the Clinton administration. These effects do not consistently attain statistical significance, though. 


\section{References}

Allegretto, Sylvia A. and Keefe, Jeffery. 2010. "The Truth about Public Employees in California: They Are Neither Overpaid Nor Overcompensated," Institute for Research on Labor and Employment, University of California, Berkeley.

Bargain, Olivier and Melly, Blaise. 2008 "Public SectorPay Gap in France: New Evidence using Panel Data." IZA Discussion Paper, No. 3427

Bewerunge, Philipp and Rosen, Harvey S. 2012 "Wage, Pensions, and Public-Private Sector Com- pensation Differentials". Griswold Center for Economic Policy Studies Working Paper, 227: $1-45$

Biggs, Andrew and Richwine, Jason. 2011 "Comparing Federal and Private Sector Compensation,"American Enterprise Institute Economic Policy Working Paper.

Borjas, George, 1980. "Wage Determination in the Federal Government: T he Role of Constituents and Bureaucrats". Journal of Political Economy, 90(2), April, pp.1110-1147.

Borjas, George, 2003. "The Wage Structure and the Sorting of Workers into the Public Sector," in Donahue, John and Nye, Joseph (eds), For the People: Can We Fix Public Service?, edited by John D. Donahue and Joseph S. Nye, Brookings Institution Press, pp. 29-54.

Bradley, David H. 2012 "Comparing Compensation for Federal and Private-Sector Workers: An Overview". CRS Report for Congress, RA2636 
Castro, Francisco et al. 2013 "The Gap between Public and Private Wages: New Evidence for the EU". European Commission, Economic Paper, No.508

Choi, Sun Ki, The Determinants and Trends in Public-Private Wage Differentials," Ph. D. dissertation, University of Kentucky, July 2016.

Congressional Budget Office. 2012. "Comparing the Compensation of Federal and PrivateSector Employees," Congress of the United States.

Congressional Budget Office. 2017. "Comparing the Compensation of Federal and PrivateSector Employees, 2011-2015," Congress of the United States.

Freeman, Richard B., 1987. "How Do Public Sector Wages and Employment Respond to Economic Conditions?," in David A. Wise, ed., Public Sector Payrolls, Chicago: University of Chicago Press, pp. 183-216.

Garen, John. 1987 "Relationships Among Estimators of Triangular Econometric Models". Economics Letter, 25: 39-41.

Giordano, Raffaela et al. 2011 "The Public Sector Pay Gap in a Selection of Euro Area Countries".European Central Bank Working Paper, No. 1460

Gittleman, Maury and Pierce, Brooks Pierce, 2012. "Compensation for State and Local Government Workers," Journal of Economic Perspectives, 26(1), Winter, pp. 217-242. 
Gyourko, Joseph, and Tracy, Joseph. "An Analysis of Public- and Private- Sector Wages Allowing for Endogenous Choices of Both Government and Union Status." Journal of Labor Economics, 6(2), April 1988, pp. 229-53.

Imbens, Guido and Wooldridge, Jeff, "What's New in Econometrics? Control Function and Related Models, Lecture Notes 6,"National Bureau of Economic Research, Summer 2007.

Katz, Lawrence F. and Krueger, Alan B. 1991 "Changes in the Structure of Wages in the Public and Private Sectors". Research in Labor Economics, 12: 137-172

Krueger, Alan B., 1988. “Are Public Sector Workers Paid More Than Their Alternative Wage? Evidence from Longitudinal Data and Job Queues," in Richard B. Freeman and Casey Ichniowski, eds., When Public Sector Workers Unionize, University of Chicago Press, pp. 217-242.

Moulton, Brent R. 1990 "A Reexamination of the Federal-Private Wage Differential in the United States". Journal of Labor Economics, 8: 270-293

Munnell, Alicia H. 2011 "Comparing Compensation: State-Local versus Private Sector workers".Center for Retirement Research at Boston University

Smith, Sharon P. 1976a "Pay Differential between Federal Government and Private-Sector Workers".Industrial and Labor Relations Review, 29: 179-197.

Smith, Sharon P. 1976b "Government Wage Differentials by Sex". The Journal of Human 
Resources. 11: 185-199.

Smith, Sharon P. 1977, “Government Wage Differentials.” Journal of Urban Economics. 4(3), July, pp. 248-271.

Van der Gaag, Jacques and Vijverberg, Wim, 1988. "A Switching Regression Model for Wage Determinants in the Public and Private Sectors of a Developing Country," Review of Economics and Statistics, 70(2), May, pp. 244-252. 
Table 1: Real Average Hourly Earnings, by Worker Category, 1995-2017 CPS MORG.

\begin{tabular}{|l|c|c|c|c|c|c|c|}
\hline & Federal & State & Local & Privte & Fede ral/Private & State/Private & Local/ Private \\
\hline \hline $\mathbf{1 9 9 5}$ & 25.842 & 21.659 & 22.420 & 19.609 & 1.318 & 1.105 & 1.143 \\
$\mathbf{1 9 9 6}$ & 25.886 & 21.516 & 21.964 & 19.315 & 1.340 & 1.114 & 1.137 \\
$\mathbf{1 9 9 7}$ & 25.943 & 21.778 & 22.162 & 19.609 & 1.323 & 1.111 & 1.130 \\
$\mathbf{1 9 9 8}$ & 26.635 & 22.451 & 22.598 & 20.476 & 1.301 & 1.096 & 1.104 \\
$\mathbf{1 9 9 9}$ & 27.646 & 22.749 & 22.956 & 20.943 & 1.320 & 1.086 & 1.096 \\
$\mathbf{2 0 0 0}$ & 27.430 & 22.722 & 22.882 & 20.991 & 1.307 & 1.082 & 1.090 \\
$\mathbf{2 0 0 1}$ & 28.212 & 23.076 & 22.974 & 21.582 & 1.307 & 1.069 & 1.064 \\
$\mathbf{2 0 0 2}$ & 28.757 & 23.749 & 23.300 & 21.890 & 1.314 & 1.085 & 1.064 \\
$\mathbf{2 0 0 3}$ & 28.617 & 23.600 & 23.199 & 21.914 & 1.306 & 1.077 & 1.059 \\
$\mathbf{2 0 0 4}$ & 29.615 & 23.688 & 23.604 & 21.932 & 1.350 & 1.080 & 1.076 \\
$\mathbf{2 0 0 5}$ & 29.971 & 23.402 & 23.100 & 21.780 & 1.376 & 1.074 & 1.061 \\
$\mathbf{2 0 0 6}$ & 30.262 & 23.349 & 23.128 & 21.689 & 1.395 & 1.077 & 1.066 \\
$\mathbf{2 0 0 7}$ & 30.594 & 23.703 & 23.468 & 21.833 & 1.401 & 1.086 & 1.075 \\
$\mathbf{2 0 0 8}$ & 29.812 & 23.762 & 23.518 & 21.985 & 1.356 & 1.081 & 1.070 \\
$\mathbf{2 0 0 9}$ & 30.813 & 24.074 & 23.924 & 22.546 & 1.367 & 1.068 & 1.061 \\
$\mathbf{2 0 1 0}$ & 30.594 & 24.286 & 24.065 & 22.339 & 1.370 & 1.087 & 1.077 \\
$\mathbf{2 0 1 1}$ & 30.505 & 23.778 & 23.873 & 22.128 & 1.379 & 1.075 & 1.079 \\
$\mathbf{2 0 1 2}$ & 31.477 & 23.579 & 23.480 & 22.281 & 1.413 & 1.058 & 1.054 \\
$\mathbf{2 0 1 3}$ & 31.772 & 23.644 & 23.507 & 22.198 & 1.431 & 1.065 & 1.059 \\
$\mathbf{2 0 1 4}$ & 30.757 & 23.692 & 23.487 & 22.204 & 1.385 & 1.067 & 1.058 \\
$\mathbf{2 0 1 5}$ & 31.050 & 24.206 & 24.249 & 22.594 & 1.374 & 1.071 & 1.073 \\
$\mathbf{2 0 1 6}$ & 31.229 & 24.228 & 24.231 & 23.078 & 1.353 & 1.050 & 1.050 \\
$\mathbf{2 0 1 7}$ & 31.171 & 24.247 & 23.965 & 22.966 & 1.357 & 1.056 & 1.044 \\
\hline
\end{tabular}

Source: Current Population Surveys

Figure 1: Trend of Real Wage Ratio between Federal and Private Sector.

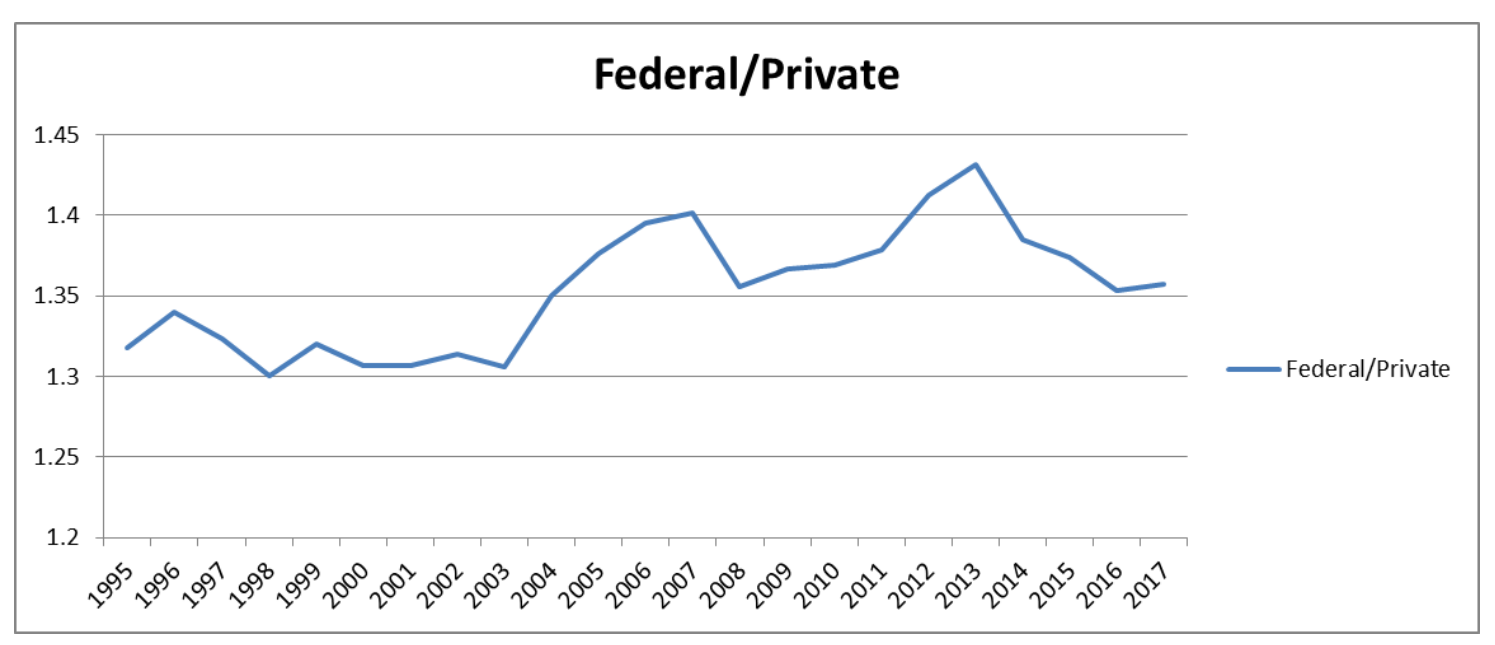


Table 2: Percentage of workers receiving fringe benefit

\begin{tabular}{|l|l|l|l|l|}
\hline \multirow{2}{*}{} & \multicolumn{2}{|c|}{ Health Insurance } & \multicolumn{2}{|c|}{ Pension Plan } \\
\cline { 2 - 5 } & Private & Federal & Private & Federal \\
\hline 1995 & 0.743 & 0.890 & 0.448 & 0.802 \\
1996 & 0.763 & 0.906 & 0.447 & 0.830 \\
1997 & 0.759 & 0.865 & 0.449 & 0.799 \\
1998 & 0.762 & 0.881 & 0.454 & 0.759 \\
1999 & 0.768 & 0.835 & 0.481 & 0.786 \\
2000 & 0.791 & 0.876 & 0.480 & 0.743 \\
2001 & 0.806 & 0.910 & 0.481 & 0.755 \\
2002 & 0.810 & 0.923 & 0.480 & 0.760 \\
2003 & 0.796 & 0.885 & 0.461 & 0.777 \\
2004 & 0.784 & 0.895 & 0.458 & 0.744 \\
2005 & 0.768 & 0.893 & 0.454 & 0.771 \\
2006 & 0.750 & 0.866 & 0.449 & 0.741 \\
2007 & 0.736 & 0.896 & 0.426 & 0.763 \\
2008 & 0.746 & 0.874 & 0.460 & 0.778 \\
2009 & 0.741 & 0.895 & 0.444 & 0.774 \\
2010 & 0.707 & 0.881 & 0.427 & 0.763 \\
2011 & 0.710 & 0.887 & 0.421 & 0.795 \\
2012 & 0.712 & 0.862 & 0.432 & 0.744 \\
2013 & 0.703 & 0.893 & 0.424 & 0.785 \\
2014 & 0.706 & 0.805 & 0.423 & 0.762 \\
2015 & 0.715 & 0.792 & 0.390 & 0.751 \\
2016 & 0.712 & 0.842 & 0.334 & 0.658 \\
2017 & 0.706 & 0.772 & 0.327 & 0.643 \\
\hline
\end{tabular}

Source: Current Population Surveys 
Figure 2 : Percentage of workers receiving Fringe Benefits (Fed. Vs. Private)
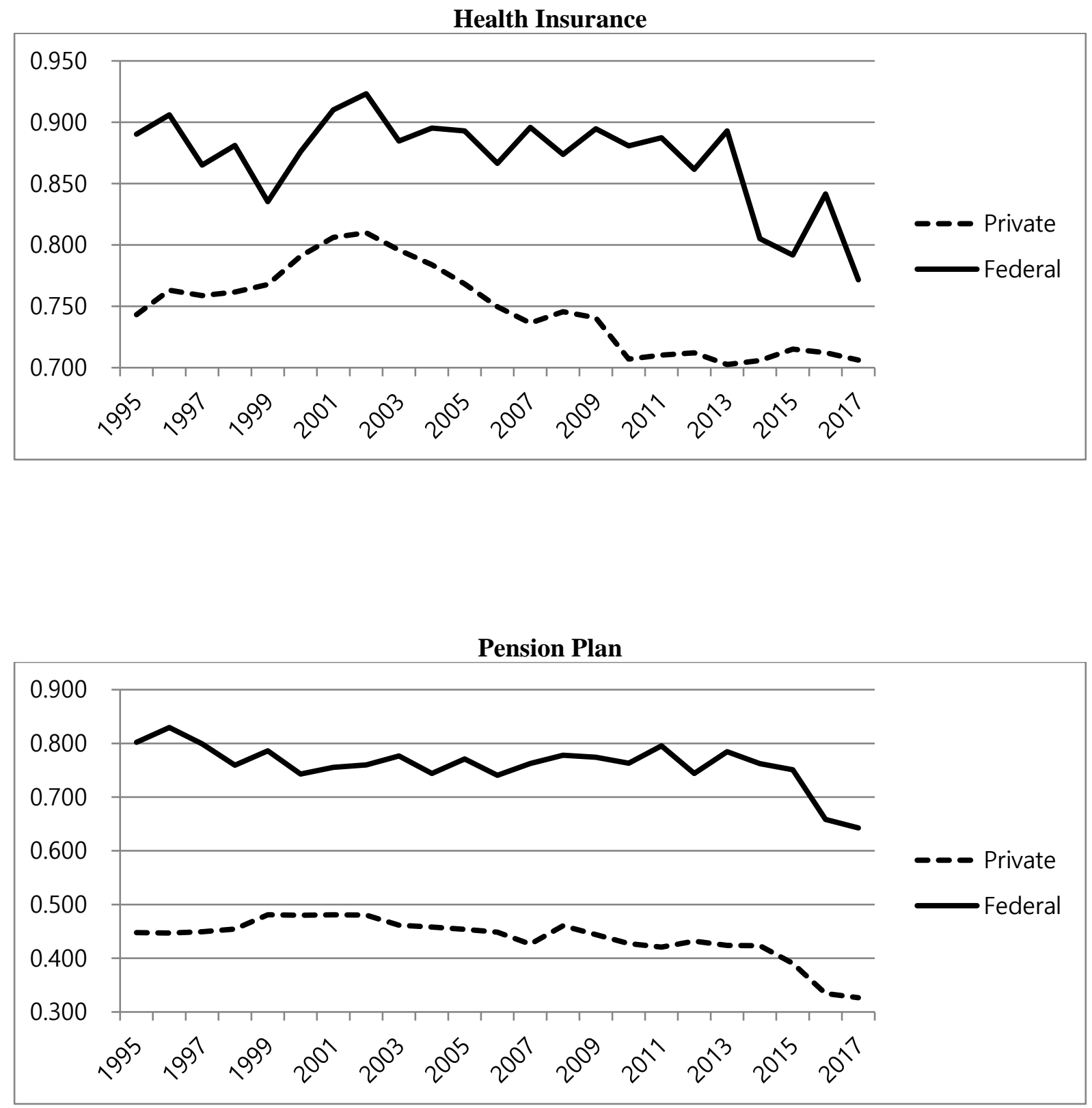
Table 3: Summary Statistics, 1995-2017 Current Population Survey Merged Outgoing Rotation Group.

\begin{tabular}{|c|c|c|c|c|c|c|}
\hline \multirow[b]{2}{*}{ Variable } & \multicolumn{2}{|c|}{ Entire Sample } & \multicolumn{2}{|c|}{ Federal } & \multicolumn{2}{|c|}{ Private } \\
\hline & Mean & Std. Dev. & Mean & Std. Dev. & Mean & Std. Dev. \\
\hline Wage & 21.933 & 13.384 & 29.459 & 15.059 & 21.669 & 13.243 \\
\hline Health Insurance & 0.757 & 0.429 & 0.873 & 0.333 & 0.753 & 0.431 \\
\hline Pension Plan & 0.452 & 0.498 & 0.759 & 0.428 & 0.441 & 0.497 \\
\hline Federal Employee & 0.032 & 0.177 & & & & \\
\hline School & 13.474 & 2.587 & 14.908 & 2.496 & 13.426 & 2.577 \\
\hline Age & 40.492 & 12.179 & 44.360 & 11.234 & 40.362 & 12.188 \\
\hline Female & 0.437 & 0.496 & 0.457 & 0.498 & 0.436 & 0.496 \\
\hline Union & 0.089 & 0.285 & 0.180 & 0.384 & 0.086 & 0.281 \\
\hline \multicolumn{7}{|l|}{ Msa } \\
\hline Metropolitan & 0.284 & 0.451 & 0.336 & 0.472 & 0.289 & 0.453 \\
\hline Balance & 0.478 & 0.500 & 0.455 & 0.498 & 0.479 & 0.500 \\
\hline Non-Metropolitan & 0.231 & 0.422 & 0.209 & 0.407 & 0.232 & 0.422 \\
\hline Experience & 21.018 & 12.321 & 23.452 & 11.507 & 20.936 & 12.339 \\
\hline \multicolumn{7}{|l|}{ Region } \\
\hline Northeast & 0.203 & 0.402 & 0.120 & 0.325 & 0.207 & 0.405 \\
\hline Midwest & 0.242 & 0.428 & 0.150 & 0.357 & 0.245 & 0.430 \\
\hline South & 0.316 & 0.465 & 0.455 & 0.498 & 0.311 & 0.463 \\
\hline West & 0.238 & 0.426 & 0.275 & 0.446 & 0.237 & 0.425 \\
\hline \multicolumn{7}{|l|}{ Race } \\
\hline White & 0.730 & 0.444 & 0.673 & 0.469 & 0.727 & 0.445 \\
\hline Black & 0.091 & 0.288 & 0.160 & 0.366 & 0.089 & 0.285 \\
\hline Asian & 0.046 & 0.208 & 0.051 & 0.220 & 0.045 & 0.208 \\
\hline Others & 0.137 & 0.344 & 0.117 & 0.321 & 0.138 & 0.345 \\
\hline \multicolumn{7}{|l|}{ Occupation } \\
\hline Management & 0.158 & 0.365 & 0.253 & 0.435 & 0.162 & 0.368 \\
\hline Professional & 0.215 & 0.411 & 0.328 & 0.469 & 0.171 & 0.377 \\
\hline Service & 0.132 & 0.339 & 0.118 & 0.323 & 0.123 & 0.328 \\
\hline Sales & 0.097 & 0.296 & 0.016 & 0.124 & 0.116 & 0.320 \\
\hline Administrative support & 0.139 & 0.346 & 0.164 & 0.371 & 0.138 & 0.345 \\
\hline Farming, fishing, and forestry & 0.011 & 0.102 & 0.008 & 0.087 & 0.012 & 0.108 \\
\hline Construction & 0.055 & 0.229 & 0.021 & 0.142 & 0.061 & 0.240 \\
\hline Installation, maintenance, and repair & 0.042 & 0.200 & 0.036 & 0.187 & 0.046 & 0.209 \\
\hline Production & 0.083 & 0.275 & 0.026 & 0.160 & 0.097 & 0.296 \\
\hline Transportation & 0.067 & 0.250 & 0.030 & 0.170 & 0.075 & 0.263 \\
\hline \multicolumn{7}{|l|}{ Locality } \\
\hline Atlanta & 0.012 & 0.108 & 0.008 & 0.091 & 0.012 & 0.109 \\
\hline Boston & 0.016 & 0.125 & 0.008 & 0.088 & 0.016 & 0.126 \\
\hline Buffalo-Niagara & 0.003 & 0.052 & 0.002 & 0.040 & 0.003 & 0.053 \\
\hline Chicago & 0.027 & 0.161 & 0.012 & 0.108 & 0.027 & 0.162 \\
\hline Cincinnati & 0.006 & 0.077 & 0.004 & 0.059 & 0.006 & 0.077 \\
\hline Cleveland & 0.009 & 0.093 & 0.005 & 0.069 & 0.009 & 0.094 \\
\hline Columbus & 0.005 & 0.069 & 0.003 & 0.057 & 0.005 & 0.070 \\
\hline
\end{tabular}


Table 3 (cont'd)

\begin{tabular}{|c|c|c|c|c|c|c|}
\hline \multirow[b]{2}{*}{ Variable } & \multicolumn{2}{|c|}{ Entire Sample } & \multicolumn{2}{|c|}{ Federal } & \multicolumn{2}{|c|}{ Private } \\
\hline & Mean & Std. Dev. & Mean & Std. Dev. & Mean & Std. Dev. \\
\hline Locality (cont'd) & & & & & & \\
\hline Dallas & 0.014 & 0.116 & 0.008 & 0.087 & 0.014 & 0.117 \\
\hline Dayton & 0.003 & 0.051 & 0.005 & 0.071 & 0.003 & 0.051 \\
\hline Denver & 0.012 & 0.107 & 0.011 & 0.105 & 0.012 & 0.107 \\
\hline Detroit & 0.015 & 0.121 & 0.006 & 0.080 & 0.015 & 0.122 \\
\hline Hartford & 0.005 & 0.072 & 0.001 & 0.037 & 0.005 & 0.073 \\
\hline Houston & 0.012 & 0.108 & 0.004 & 0.064 & 0.012 & 0.109 \\
\hline Huntsville & 0.002 & 0.043 & 0.005 & 0.070 & 0.002 & 0.042 \\
\hline Indianapolis & 0.005 & 0.069 & 0.004 & 0.060 & 0.005 & 0.070 \\
\hline Los Angeles & 0.033 & 0.180 & 0.017 & 0.128 & 0.034 & 0.181 \\
\hline Miami & 0.012 & 0.108 & 0.006 & 0.079 & 0.012 & 0.109 \\
\hline Milwaukee & 0.006 & 0.079 & 0.002 & 0.047 & 0.006 & 0.080 \\
\hline Minneapolis & 0.013 & 0.114 & 0.005 & 0.071 & 0.014 & 0.115 \\
\hline New York & 0.045 & 0.208 & 0.022 & 0.145 & 0.046 & 0.210 \\
\hline Philadelphia & 0.021 & 0.145 & 0.016 & 0.124 & 0.022 & 0.145 \\
\hline Phoenix & 0.010 & 0.097 & 0.005 & 0.069 & 0.010 & 0.098 \\
\hline Pittsburgh & 0.007 & 0.084 & 0.003 & 0.058 & 0.007 & 0.084 \\
\hline Portland & 0.008 & 0.088 & 0.004 & 0.065 & 0.008 & 0.089 \\
\hline Raleigh & 0.004 & 0.067 & 0.003 & 0.051 & 0.005 & 0.067 \\
\hline Richmond & 0.003 & 0.056 & 0.004 & 0.061 & 0.003 & 0.055 \\
\hline Sacramento & 0.004 & 0.061 & 0.003 & 0.051 & 0.004 & 0.061 \\
\hline San Diego & 0.006 & 0.077 & 0.010 & 0.098 & 0.006 & 0.076 \\
\hline San Jose & 0.014 & 0.119 & 0.009 & 0.094 & 0.014 & 0.120 \\
\hline Seattle & 0.010 & 0.098 & 0.008 & 0.088 & 0.010 & 0.098 \\
\hline Washington & 0.039 & 0.194 & 0.213 & 0.409 & 0.033 & 0.180 \\
\hline State of Alaska & 0.011 & 0.103 & 0.031 & 0.174 & 0.010 & 0.099 \\
\hline State of Hawaii & 0.012 & 0.110 & 0.029 & 0.167 & 0.012 & 0.107 \\
\hline Rest of U.S. & 0.606 & 0.489 & 0.527 & 0.499 & 0.600 & 0.490 \\
\hline
\end{tabular}

Source: Current Population Surveys

Note: Definitions of Variables: Hourly Wage: The wage rate is used, if reported. Otherwise, this is reported earning divided by reported usual hours over that time span. Public: This variable is created from the 'Class of Job' survey question. State and local government workers are dropped from sample. As a result, federal government workers have value for this variable equal to 1 and 0 for private sector workers. School: This variable indicates the number of years of education the workers attained. Experience: Potential experience (=Age- School -6). Female: If a worker who interviewed is female, then the value for this variable is 1 and 0 . Union: equal 1 for union members, 0 otherwise. Race: There are four race dummy variables one each for White, Black, Asian, others. Region: There are four region dummy variables, one each Northeast, Midwest, South, and West. MSA: This variable defines the 'Metropolitan Statistical Area' status. Separate dummies are created in the city of an MSA, the balance of the MSA, and non-metropolitan location. Occupation: Dummies variables are created for ten major occupations. Locality: This variable indicates 33 separate metropolitan locality pay areas and one variable for "Rest of U.S.". Federal government offers 34 different wage schedules which are depending on the location and cost of living. 
Table 4 : Detailed Summary of Key Variables in Federal Government and Private Sector Workers, Year-by-Year, 1995-2017 CPS MORG

\begin{tabular}{|c|c|c|c|c|c|c|c|c|c|c|c|c|c|c|c|c|c|c|}
\hline & \multicolumn{2}{|c|}{ School } & \multicolumn{2}{|c|}{ Age } & \multicolumn{2}{|c|}{ Female } & \multicolumn{2}{|c|}{ Union } & \multicolumn{2}{|c|}{ White } & \multicolumn{2}{|c|}{ Management } & \multicolumn{2}{|c|}{ Professional } & \multicolumn{2}{|c|}{ Sevice } & \multicolumn{2}{|c|}{ Administation } \\
\hline & Federal & Private & Federal & Private & Federal & Private & Federal & Private & Federal & Private & Federal & Private & Federal & Private & Federal & Private & Federal & Private \\
\hline 1995 & 14.3520 & 13.1231 & 42.4799 & 38.1402 & 0.4721 & 0.4291 & 0.1915 & 0.1153 & 0.7019 & 0.7849 & 0.2809 & 0.1464 & 0.2937 & 0.1449 & 0.0840 & 0.1014 & 0.2059 & 0.1472 \\
\hline 1996 & 14.3688 & 13.1070 & 43.0279 & 38.3341 & 0.4679 & 0.4309 & 0.1890 & 0.1114 & 0.7076 & 0.7789 & 0.2771 & 0.1477 & 0.2940 & 0.1448 & 0.0838 & 0.1034 & 0.1976 & 0.1453 \\
\hline 1997 & 14.4591 & 13.1132 & 42.8133 & 38.4340 & 0.4667 & 0.4328 & 0.1779 & 0.1070 & 0.7200 & 0.7689 & 0.2695 & 0.1506 & 0.2990 & 0.1488 & 0.0938 & 0.1022 & 0.1985 & 0.1416 \\
\hline 1998 & 14.4598 & 13.1454 & 43.3043 & 38.6617 & 0.4695 & 0.4326 & 0.1893 & 0.1054 & 0.7098 & 0.7631 & 0.2780 & 0.1526 & 0.2947 & 0.1520 & 0.0938 & 0.1037 & 0.1957 & 0.1420 \\
\hline 1999 & 14.5862 & 13.1630 & 43.9659 & 38.8884 & 0.4572 & 0.4308 & 0.1873 & 0.1049 & 0.7039 & 0.7564 & 0.2945 & 0.1557 & 0.2993 & 0.1546 & 0.0916 & 0.1044 & 0.1803 & 0.1378 \\
\hline 2000 & 14.5201 & 13.1698 & 43.9679 & 38.9645 & 0.4402 & 0.4314 & 0.1761 & 0.0998 & 0.7013 & 0.7412 & 0.2705 & 0.1560 & 0.3102 & 0.1552 & 0.0857 & 0.1035 & 0.1906 & 0.1394 \\
\hline 2001 & 14.6314 & 13.2293 & 44.1584 & 39.3028 & 0.4558 & 0.4328 & 0.1921 & 0.0983 & 0.7020 & 0.7436 & 0.2753 & 0.1603 & 0.3173 & 0.1601 & 0.0901 & 0.1057 & 0.1699 & 0.1366 \\
\hline 2002 & 14.6452 & 13.2728 & 44.3165 & 39.6607 & 0.4746 & 0.4348 & 0.1849 & 0.0945 & 0.6835 & 0.7515 & 0.2768 & 0.1638 & 0.3129 & 0.1622 & 0.1056 & 0.1073 & 0.1745 & 0.1339 \\
\hline 2003 & 14.6188 & 13.2896 & 44.3450 & 39.9761 & 0.4790 & 0.4379 & 0.1840 & 0.0895 & 0.6788 & 0.7451 & 0.2368 & 0.1505 & 0.3164 & 0.1624 & 0.1211 & 0.1251 & 0.1822 & 0.1509 \\
\hline 2004 & 14.6744 & 13.3073 & 44.6819 & 40.1246 & 0.4604 & 0.4355 & 0.1735 & 0.0866 & 0.6773 & 0.7375 & 0.2322 & 0.1509 & 0.3248 & 0.1635 & 0.1345 & 0.1289 & 0.1615 & 0.1467 \\
\hline 2005 & 14.7823 & 13.3197 & 44.7881 & 40.2127 & 0.4494 & 0.4349 & 0.1699 & 0.0845 & 0.6800 & 0.7313 & 0.2319 & 0.1510 & 0.3158 & 0.1647 & 0.1330 & 0.1277 & 0.1725 & 0.1460 \\
\hline 2006 & 14.8534 & 13.3316 & 45.0279 & 40.3514 & 0.4515 & 0.4338 & 0.1719 & 0.0804 & 0.6737 & 0.7183 & 0.2285 & 0.1528 & 0.3276 & 0.1644 & 0.1268 & 0.1302 & 0.1797 & 0.1446 \\
\hline 2007 & 14.9815 & 13.3927 & 44.7131 & 40.5955 & 0.4449 & 0.4372 & 0.1559 & 0.0803 & 0.6592 & 0.7136 & 0.2399 & 0.1573 & 0.3355 & 0.1676 & 0.1239 & 0.1289 & 0.1622 & 0.1424 \\
\hline 2008 & 14.9397 & 13.4673 & 44.7791 & 40.8612 & 0.4634 & 0.4377 & 0.1768 & 0.0826 & 0.6614 & 0.7164 & 0.2352 & 0.1611 & 0.3384 & 0.1737 & 0.1180 & 0.1308 & 0.1619 & 0.1409 \\
\hline 2009 & 14.9973 & 13.5470 & 44.8439 & 41.3024 & 0.4676 & 0.4424 & 0.1793 & 0.0774 & 0.6686 & 0.7188 & 0.2473 & 0.1678 & 0.3208 & 0.1823 & 0.1334 & 0.1364 & 0.1556 & 0.1390 \\
\hline 2010 & 15.0283 & 13.5974 & 44.2943 & 41.4373 & 0.4512 & 0.4442 & 0.1750 & 0.0758 & 0.6533 & 0.7142 & 0.2282 & 0.1656 & 0.3322 & 0.1870 & 0.1419 & 0.1381 & 0.1601 & 0.1397 \\
\hline 2011 & 15.1276 & 13.6381 & 44.6907 & 41.6339 & 0.4502 & 0.4418 & 0.1800 & 0.0750 & 0.6678 & 0.7113 & 0.2422 & 0.1684 & 0.3447 & 0.1873 & 0.1281 & 0.1362 & 0.1495 & 0.1375 \\
\hline 2012 & 15.2929 & 13.6938 & 44.6459 & 41.7773 & 0.4527 & 0.4363 & 0.1675 & 0.0713 & 0.6668 & 0.7067 & 0.2505 & 0.1755 & 0.3602 & 0.1876 & 0.1267 & 0.1359 & 0.1416 & 0.1319 \\
\hline 2013 & 15.3905 & 13.7482 & 44.9923 & 41.8899 & & 0.4383 & 0.1796 & 0.0724 & & & 0.2557 & 0.1760 & 0.3489 & 0.1909 & 0.1347 & 0.1338 & 0.1404 & 0.1311 \\
\hline 2014 & 15.4022 & 13.7482 & 44.8234 & 41.9066 & & 0.4369 & & 0.0717 & 0.6324 & & 0.2497 & 0.1746 & 0.3526 & 0.1918 & 0.1320 & 0.1334 & 0.1401 & 0.1298 \\
\hline 2015 & 15.4354 & 13.7598 & 44.9279 & 41.8763 & 0.4666 & 0.4380 & 0.1846 & 0.0702 & 0.6402 & 0.6839 & 0.2363 & 0.1757 & 0.3595 & 0.1952 & 0.1376 & 0.1332 & 0.1391 & 0.1277 \\
\hline 2016 & 15.4070 & 13.7987 & 44.7671 & 41.8243 & 0.4353 & 0.4375 & 0.1799 & 0.0675 & 0.6453 & 0.6764 & 0.2622 & 0.1783 & 0.3547 & 0.1965 & 0.1338 & 0.1358 & 0.1241 & 0.1252 \\
\hline 2017 & 15.4471 & 13.8502 & 45.0219 & 41.9834 & 0.4379 & 0.4393 & 0.1826 & 0.0685 & 0.6310 & 0.6753 & 0.2495 & 0.1800 & 0.3604 & 0.2007 & 0.1376 & 0.1331 & 0.1300 & 0.1203 \\
\hline
\end{tabular}

Source: Current Population Surveys 
Table 5: Wage Differential, OLS, Year-by-Year, 1995-2017 CPS MORG

\begin{tabular}{|c|c|}
\hline & OLS Wage Differential \\
\hline 1995 & $\begin{array}{c}0.123 * * * \\
(0.016)\end{array}$ \\
\hline 1996 & $\begin{array}{c}0.123^{* * *} \\
(0.018)\end{array}$ \\
\hline 1997 & $\begin{array}{c}0.096^{* * * *} \\
(0.019)\end{array}$ \\
\hline 1998 & $\begin{array}{c}0.052^{* * *} \\
(0.022)\end{array}$ \\
\hline 1999 & $\begin{array}{l}0.034 \\
(0.028)\end{array}$ \\
\hline 2000 & $\begin{array}{c}0.080 * * * \\
(0.015)\end{array}$ \\
\hline 2001 & $\begin{array}{c}0.083 * * * \\
(0.014)\end{array}$ \\
\hline 2002 & $\begin{array}{c}0.079 * * * \\
(0.015)\end{array}$ \\
\hline 2003 & $\begin{array}{c}0.119 * * * \\
(0.018)\end{array}$ \\
\hline 2004 & $\begin{array}{c}0.094 * * * \\
(0.016)\end{array}$ \\
\hline 2005 & $\begin{array}{c}0.132 * * * \\
(0.015)\end{array}$ \\
\hline 2006 & $\begin{array}{c}0.154 * * * \\
(0.017)\end{array}$ \\
\hline 2007 & $\begin{array}{c}0.157 * * * \\
(0.015)\end{array}$ \\
\hline 2008 & $\begin{array}{c}0.152 * * * \\
(0.014)\end{array}$ \\
\hline 2009 & $\begin{array}{c}0.160 * * * \\
(0.014)\end{array}$ \\
\hline 2010 & $\begin{array}{c}0.163 * * * \\
(0.015)\end{array}$ \\
\hline 2011 & $\begin{array}{c}0.144 * * * \\
(0.017)\end{array}$ \\
\hline 2012 & $\begin{array}{c}0.155^{* * * *} \\
(0.020)\end{array}$ \\
\hline 2013 & $\begin{array}{c}0.177 * * * \\
(0.018)\end{array}$ \\
\hline 2014 & $\begin{array}{c}0.132 * * \\
(0.053)\end{array}$ \\
\hline 2015 & $\begin{array}{c}0.114 * * * \\
(0.016)\end{array}$ \\
\hline 2016 & $\begin{array}{c}0.135 * * * \\
(0.016)\end{array}$ \\
\hline 2017 & $\begin{array}{c}0.122 * * * \\
(0.018)\end{array}$ \\
\hline
\end{tabular}


Table 6: Wage Differential, OLS, Year-by-Year, 4 Occupations, 1995-2017 CPS MORG

\begin{tabular}{|c|c|}
\hline & OLS Wage Diffe rential (4 Occ.) \\
\hline 1995 & $\begin{array}{c}0.139 * * * \\
(0.013)\end{array}$ \\
\hline 1996 & $\begin{array}{c}0.133 * * * \\
(0.012)\end{array}$ \\
\hline 1997 & $\begin{array}{c}0.132 * * * \\
(0.013)\end{array}$ \\
\hline 1998 & $\begin{array}{c}0.100^{* * *} \\
(0.015)\end{array}$ \\
\hline 1999 & $\begin{array}{c}0.099 * * * \\
(0.014)\end{array}$ \\
\hline 2000 & $\begin{array}{c}0.086^{* * * *} \\
(0.015)\end{array}$ \\
\hline 2001 & $\begin{array}{c}0.114 * * * \\
(0.013)\end{array}$ \\
\hline 2002 & $\begin{array}{c}0.118^{* * * *} \\
(0.012)\end{array}$ \\
\hline 2003 & $\begin{array}{c}0.082^{* * * *} \\
(0.014)\end{array}$ \\
\hline 2004 & $\begin{array}{c}0.108 * * * \\
(0.014)\end{array}$ \\
\hline 2005 & $\begin{array}{c}0.123 * * * \\
(0.014)\end{array}$ \\
\hline 2006 & $\begin{array}{c}0.147 * * * \\
(0.014)\end{array}$ \\
\hline 2007 & $\begin{array}{c}0.160 * * * \\
(0.015)\end{array}$ \\
\hline 2008 & $\begin{array}{c}0.154 * * * \\
(0.013)\end{array}$ \\
\hline 2009 & $\begin{array}{c}0.148^{* * * *} \\
(0.014)\end{array}$ \\
\hline 2010 & $\begin{array}{c}0.156^{* * * *} \\
(0.014)\end{array}$ \\
\hline 2011 & $\begin{array}{c}0.136^{* * *} \\
(0.014)\end{array}$ \\
\hline 2012 & $\begin{array}{c}0.151^{* * * *} \\
(0.019)\end{array}$ \\
\hline 2013 & $\begin{array}{c}0.169 * * * \\
(0.016)\end{array}$ \\
\hline 2014 & $\begin{array}{c}0.147 * * * \\
(0.039)\end{array}$ \\
\hline 2015 & $\begin{array}{c}0.116^{* * * *} \\
(0.015)\end{array}$ \\
\hline 2016 & $\begin{array}{c}0.118^{* * *} \\
(0.015)\end{array}$ \\
\hline 2017 & $\begin{array}{c}0.104 * * * \\
(0.017)\end{array}$ \\
\hline
\end{tabular}

Note: standard errors in parentheses $* * * \mathrm{p}<0.01, * * \mathrm{p}<0.05, * \mathrm{p}<0$ Source: Current Population Surveys 
Figure 3 : Wage Differential, OLS, Year-by-Year, 1995-2017 CPS MORG

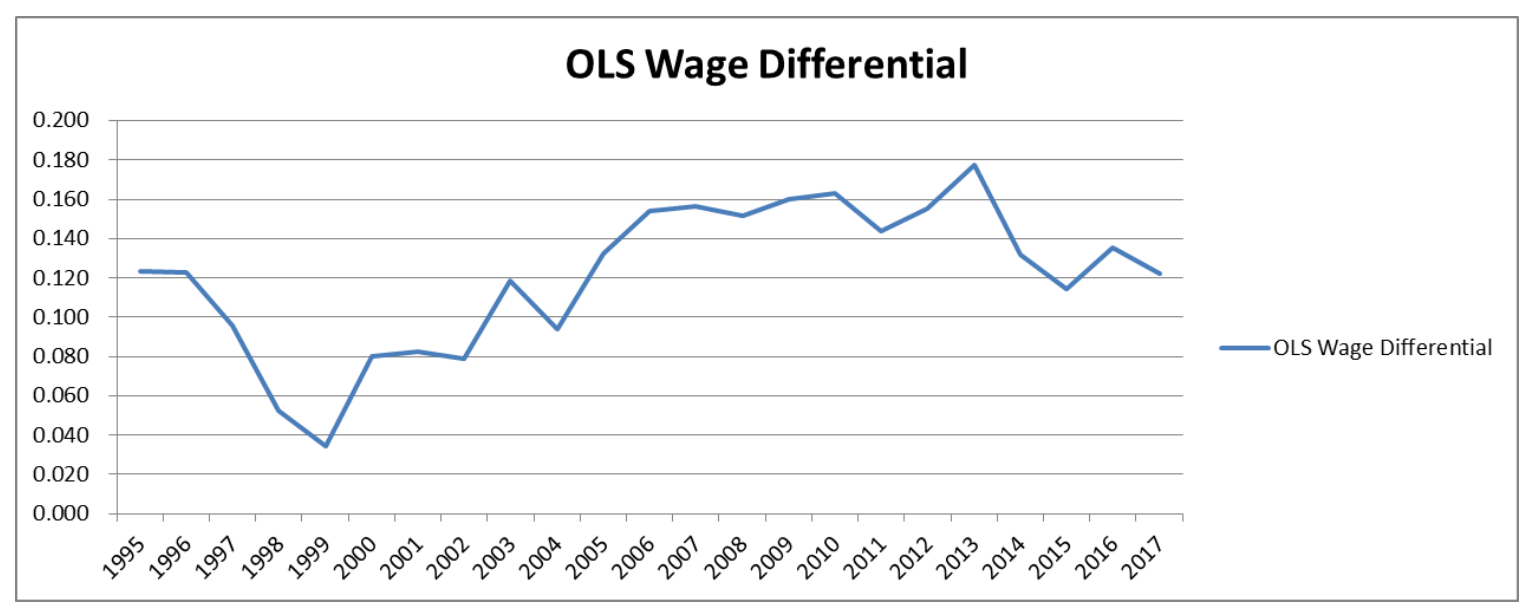

Figure 4: Wage Differential, OLS, Year-by-Year, 4 Occupations, 1995-2017 CPS MORG

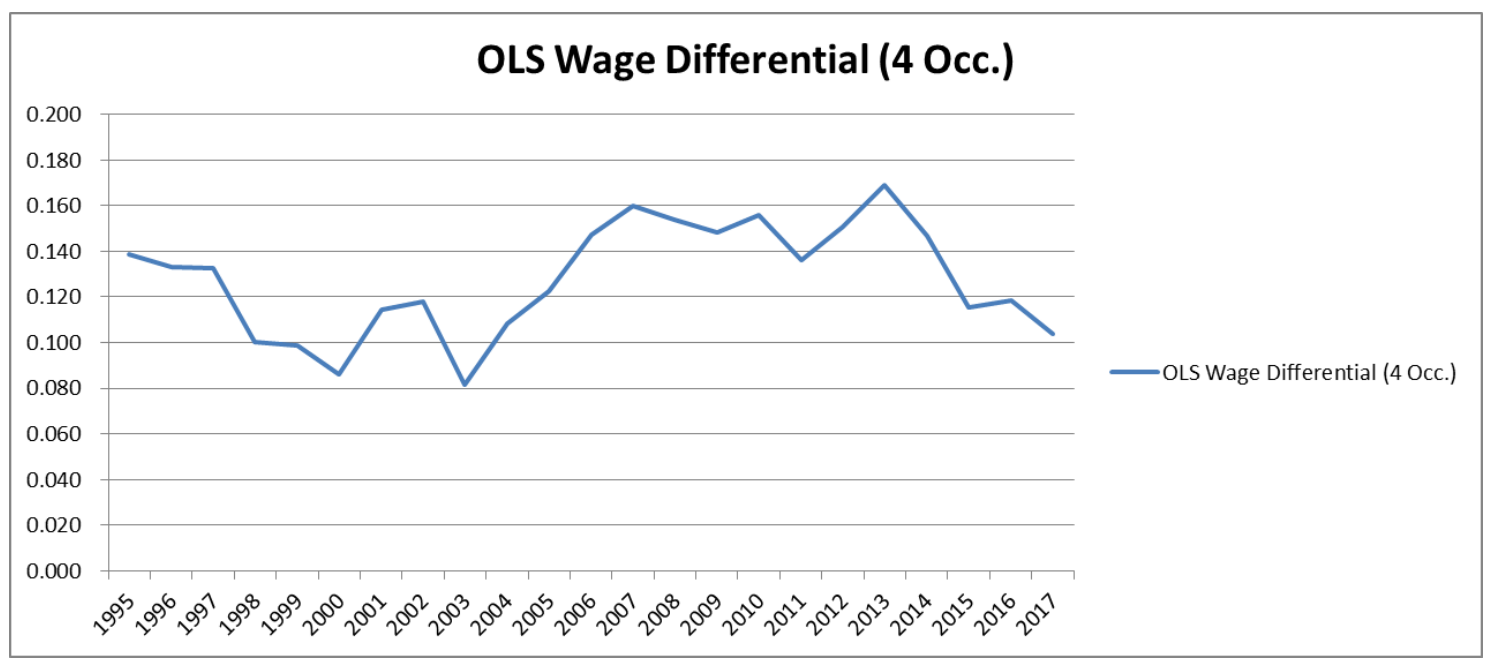


Table 7: Differences in Coefficients of inverse Mills ratio, Year-by-Year, Each Sector

\begin{tabular}{|c|c|c|c|}
\hline & Federal IMR Coefficient & Private IMR Coefficient & Difference \\
\hline 1995 & $\begin{array}{c}0.147 \\
(0.096)\end{array}$ & $\begin{array}{c}0.262 * * * \\
(0.044)\end{array}$ & $\begin{array}{l}-0.114 \\
(0.124)\end{array}$ \\
\hline 1996 & $\begin{array}{l}0.180 \\
(0.133)\end{array}$ & $\begin{array}{c}0.296 * * * \\
(0.041)\end{array}$ & $\begin{array}{l}-0.116 \\
(0.123)\end{array}$ \\
\hline 1997 & $\begin{array}{l}0.256 * * \\
(0.119)\end{array}$ & $\begin{array}{c}0.418 * * * \\
(0.041)\end{array}$ & $\begin{array}{l}-0.162 \\
(0.139)\end{array}$ \\
\hline 1998 & $\begin{array}{l}-0.148 \\
(0.201)\end{array}$ & $\begin{array}{c}0.376^{* * * *} \\
(0.046)\end{array}$ & $\begin{array}{c}-0.524 * * \\
(0.211)\end{array}$ \\
\hline 1999 & $\begin{array}{l}-0.083 \\
(0.210)\end{array}$ & $\begin{array}{c}0.205^{* * * *} \\
(0.043)\end{array}$ & $\begin{array}{l}-0.288 \\
(0.188)\end{array}$ \\
\hline 2000 & $\begin{array}{c}-0.399 * * * \\
(0.132)\end{array}$ & $\begin{array}{c}0.402 * * * \\
(0.044)\end{array}$ & $\begin{array}{c}-0.801 * * * \\
(0.171)\end{array}$ \\
\hline 2001 & $\begin{array}{l}0.116 \\
(0.085)\end{array}$ & $\begin{array}{c}0.510 * * * \\
(0.042)\end{array}$ & $\begin{array}{c}-0.394 * * * \\
(0.131)\end{array}$ \\
\hline 2002 & $\begin{array}{l}0.025 \\
(0.084)\end{array}$ & $\begin{array}{c}0.253^{* * * *} \\
(0.039)\end{array}$ & $\begin{array}{c}-0.228 * * * \\
(0.086)\end{array}$ \\
\hline 2003 & $\begin{array}{l}0.108 \\
(0.104)\end{array}$ & $\begin{array}{c}0.300 * * * \\
(0.047)\end{array}$ & $\begin{array}{l}-0.192 \\
(0.122)\end{array}$ \\
\hline 2004 & $\begin{array}{l}0.297 * * * \\
(0.108)\end{array}$ & $\begin{array}{c}0.352 * * * \\
(0.043)\end{array}$ & $\begin{array}{l}-0.056 \\
(0.121)\end{array}$ \\
\hline 2005 & $\begin{array}{l}0.123 \\
(0.150)\end{array}$ & $\begin{array}{c}0.286^{* * * *} \\
(0.043)\end{array}$ & $\begin{array}{l}-0.163 \\
(0.144)\end{array}$ \\
\hline 2006 & $\begin{array}{l}0.005 \\
(0.125)\end{array}$ & $\begin{array}{c}0.225 * * * \\
(0.043)\end{array}$ & $\begin{array}{l}-0.221 * \\
(0.127)\end{array}$ \\
\hline 2007 & $\begin{array}{c}0.093 \\
(0.100)\end{array}$ & $\begin{array}{c}0.235^{* * * *} \\
(0.046)\end{array}$ & $\begin{array}{l}-0.142 \\
(0.111)\end{array}$ \\
\hline 2008 & $\begin{array}{l}-0.066 \\
(0.083)\end{array}$ & $\begin{array}{c}0.196 * * * \\
(0.045)\end{array}$ & $\begin{array}{c}-0.262^{* * *} \\
(0.072)\end{array}$ \\
\hline 2009 & $\begin{array}{l}-0.115 \\
(0.106)\end{array}$ & $\begin{array}{c}0.182 * * * \\
(0.047)\end{array}$ & $\begin{array}{c}-0.297 * * * \\
(0.107)\end{array}$ \\
\hline 2010 & $\begin{array}{l}-0.006 \\
(0.130)\end{array}$ & $\begin{array}{c}0.373^{* * * *} \\
(0.049)\end{array}$ & $\begin{array}{c}-0.379 * * \\
(0.145)\end{array}$ \\
\hline 2011 & $\begin{array}{l}0.232 * * \\
(0.097)\end{array}$ & $\begin{array}{c}0.199 * * * \\
(0.045)\end{array}$ & $\begin{array}{c}0.032 \\
(0.121)\end{array}$ \\
\hline 2012 & $\begin{array}{l}0.009 \\
(0.134)\end{array}$ & $\begin{array}{c}0.176^{* * * *} \\
(0.046)\end{array}$ & $\begin{array}{l}-0.167 \\
(0.159)\end{array}$ \\
\hline 2013 & $\begin{array}{l}-0.017 \\
(0.104)\end{array}$ & $\begin{array}{c}0.133^{* * * *} \\
(0.044)\end{array}$ & $\begin{array}{l}-0.150 \\
(0.112)\end{array}$ \\
\hline 2014 & $\begin{array}{l}-0.237 \\
(0.222)\end{array}$ & $\begin{array}{c}0.075 \\
(0.084)\end{array}$ & $\begin{array}{l}-0.162 \\
(0.181)\end{array}$ \\
\hline 2015 & $\begin{array}{l}0.153 \\
(0.118)\end{array}$ & $\begin{array}{c}0.208^{* * * *} \\
(0.046)\end{array}$ & $\begin{array}{l}-0.055 \\
(0.122)\end{array}$ \\
\hline 2016 & $\begin{array}{l}-0.062 \\
(0.114)\end{array}$ & $\begin{array}{c}0.249 * * * \\
(0.047)\end{array}$ & $\begin{array}{c}-0.311 * * \\
(0.116)\end{array}$ \\
\hline 2017 & $\begin{array}{l}-0.089 \\
(0.132)\end{array}$ & $\begin{array}{c}0.156^{* * *} \\
(0.048)\end{array}$ & $\begin{array}{c}-0.245^{* *} \\
(0.101)\end{array}$ \\
\hline
\end{tabular}

Note: standard errors in parentheses ${ }^{* * *} \mathrm{p}<0.01, * * \mathrm{p}<0.05,{ }^{*} \mathrm{p}<0.1$

Source: Current Population Surveys 
Table 8: Differences in Coefficients of inverse Mills ratio, Year-by-Year, Each Sector, 4 Occupations

\begin{tabular}{|c|c|c|c|}
\hline & Federal IMR Coefficient & Private IMR Coefficient & Difference \\
\hline \multirow[t]{2}{*}{1995} & $\begin{array}{l}0.117 \\
\end{array}$ & $0.153^{* *}$ & -0.036 \\
\hline & $(0.119)$ & $(0.044)$ & $(0.117)$ \\
\hline \multirow[t]{2}{*}{1996} & $0.314^{*}$ & $0.268 * * *$ & 0.046 \\
\hline & $(0.161)$ & $(0.060)$ & $(0.148)$ \\
\hline \multirow[t]{2}{*}{1997} & $0.353^{* *}$ & $0.331 * * *$ & 0.022 \\
\hline & $(0.158)$ & $(0.063)$ & $(0.214)$ \\
\hline \multirow[t]{2}{*}{1998} & 0.036 & 0.087 & -0.050 \\
\hline & $(0.215)$ & $(0.073)$ & $(0.252)$ \\
\hline \multirow[t]{2}{*}{1999} & -0.287 & 0.080 & -0.367 \\
\hline & $(0.288)$ & $(0.063)$ & $(0.509)$ \\
\hline \multirow[t]{2}{*}{2000} & $-0.387 * * *$ & $0.253 * * *$ & $-0.640 * * *$ \\
\hline & $(0.136)$ & $(0.063)$ & $(0.220)$ \\
\hline \multirow[t]{2}{*}{2001} & 0.157 & $0.434 * * *$ & $-0.277 * *$ \\
\hline & $(0.106)$ & $(0.055)$ & $(0.140)$ \\
\hline \multirow[t]{2}{*}{2002} & 0.093 & $0.177 * * *$ & -0.084 \\
\hline & $(0.099)$ & $(0.056)$ & $(0.088)$ \\
\hline \multirow[t]{2}{*}{2003} & 0.087 & $0.389 * * *$ & $-0.301 * *$ \\
\hline & $(0.114)$ & $(0.065)$ & $(0.118)$ \\
\hline \multirow[t]{2}{*}{2004} & $0.290 * *$ & $0.360 * * *$ & -0.070 \\
\hline & $(0.119)$ & $(0.061)$ & $(0.151)$ \\
\hline \multirow[t]{2}{*}{2005} & 0.220 & $0.206 * * *$ & 0.014 \\
\hline & (0.158) & $(0.062)$ & (0.196) \\
\hline \multirow[t]{2}{*}{2006} & 0.013 & $0.151^{* *}$ & -0.138 \\
\hline & (0.126) & $(0.061)$ & (0.110) \\
\hline \multirow[t]{2}{*}{2007} & 0.097 & $0.138^{* *}$ & -0.041 \\
\hline & (0.099) & $(0.063)$ & $(0.114)$ \\
\hline \multirow[t]{2}{*}{2008} & -0.091 & $0.212 * * *$ & $-0.302 * * *$ \\
\hline & (0.095) & $(0.058)$ & $(0.098)$ \\
\hline \multirow[t]{2}{*}{2009} & -0.126 & $0.161 * *$ & $-0.288 * * *$ \\
\hline & (0.128) & $(0.065)$ & $(0.105)$ \\
\hline \multirow[t]{2}{*}{2010} & 0.059 & $0.405^{* * *}$ & $-0.347 * *$ \\
\hline & $(0.156)$ & $(0.069)$ & $(0.147)$ \\
\hline \multirow[t]{2}{*}{2011} & $0.231 * *$ & $0.149 * *$ & 0.082 \\
\hline & $(0.106)$ & $(0.061)$ & $(0.101)$ \\
\hline \multirow[t]{2}{*}{2012} & -0.049 & $0.176^{* * *}$ & $-0.225^{*}$ \\
\hline & (0.149) & $(0.064)$ & $(0.134)$ \\
\hline \multirow[t]{2}{*}{2013} & -0.021 & $0.181 * * *$ & $-.203^{*}$ \\
\hline & (0.108) & $(0.058)$ & $(0.112)$ \\
\hline \multirow[t]{2}{*}{2014} & -0.388 & -0.020 & $-0.368^{*}$ \\
\hline & $(0.237)$ & $(0.107)$ & $(0.192)$ \\
\hline \multirow[t]{2}{*}{2015} & 0.100 & $0.226^{* * *}$ & -0.127 \\
\hline & $(0.117)$ & $(0.062)$ & $(0.169)$ \\
\hline \multirow[t]{2}{*}{2016} & -0.042 & $0.197 * * *$ & $-0.239 * *$ \\
\hline & $(0.126)$ & $(0.064)$ & $(0.120)$ \\
\hline \multirow[t]{2}{*}{2017} & -0.088 & 0.091 & -0.180 \\
\hline & $(0.145)$ & $(0.064)$ & $(0.116)$ \\
\hline
\end{tabular}

Note: standard errors in parentheses $* * * \mathrm{p}<0.01, * * \mathrm{p}<0.05, * \mathrm{p}<0.1$

Source: Current Population Surveys 
Table 9: Wage Differential using Heckman Selection Model, Year-by-Year, CPS ORG

\begin{tabular}{|c|c|}
\hline & Wage Differential (Heckman) \\
\hline 1995 & $\begin{array}{c}0.131 * * * \\
(0.021)\end{array}$ \\
\hline 1996 & $\begin{array}{c}0.129 * * * \\
(0.018)\end{array}$ \\
\hline 1997 & $\begin{array}{c}0.101 * * * \\
(0.020)\end{array}$ \\
\hline 1998 & $\begin{array}{l}0.048^{* *} \\
(0.025)\end{array}$ \\
\hline 1999 & $\begin{array}{l}0.034 \\
(0.029)\end{array}$ \\
\hline 2000 & $\begin{array}{c}0.079 * * * \\
(0.019)\end{array}$ \\
\hline 2001 & $\begin{array}{c}0.082 * * * \\
(0.015)\end{array}$ \\
\hline 2002 & $\begin{array}{l}0.079 * * * \\
(0.015)\end{array}$ \\
\hline 2003 & $\begin{array}{c}0.118^{* * * *} \\
(0.019)\end{array}$ \\
\hline 2004 & $\begin{array}{l}0.099 * * * \\
(0.016)\end{array}$ \\
\hline 2005 & $\begin{array}{l}0.133 * * * \\
(0.015)\end{array}$ \\
\hline 2006 & $\begin{array}{c}0.154 * * * \\
(0.015)\end{array}$ \\
\hline 2007 & $\begin{array}{l}0.158 * * * \\
(0.017)\end{array}$ \\
\hline 2008 & $\begin{array}{l}0.148 * * * \\
(0.015)\end{array}$ \\
\hline 2009 & $\begin{array}{c}0.152 * * * \\
(0.017)\end{array}$ \\
\hline 2010 & $\begin{array}{l}0.161 * * * \\
(0.017)\end{array}$ \\
\hline 2011 & $\begin{array}{l}0.158 * * * \\
(0.018)\end{array}$ \\
\hline 2012 & $\begin{array}{c}0.155^{* * * *} \\
(0.021)\end{array}$ \\
\hline 2013 & $\begin{array}{c}0.177 * * * \\
(0.019)\end{array}$ \\
\hline 2014 & $\begin{array}{l}0.124 * * \\
(0.050)\end{array}$ \\
\hline 2015 & $\begin{array}{l}0.112 * * * \\
(0.016)\end{array}$ \\
\hline 2016 & $\begin{array}{c}0.138 * * * \\
(0.019)\end{array}$ \\
\hline 2017 & $\begin{array}{l}0.125^{* * * *} \\
(0.018)\end{array}$ \\
\hline
\end{tabular}

Note: standard errors in parentheses ${ }^{* * *} \mathrm{p}<0.01, * * \mathrm{p}<0.05, * \mathrm{p}<0.1$ Source: Current Population Surveys 
Table 10: Wage Differential using Heckman Selection Model, Year-by-Year, 4 Occupation, CPS ORG

\begin{tabular}{|c|c|}
\hline & Wage Differential(Heckman, 4 Occupation) \\
\hline 1995 & $\begin{array}{c}0.146^{* * * *} \\
(0.018)\end{array}$ \\
\hline 1996 & $\begin{array}{c}0.143^{* * * *} \\
(0.017)\end{array}$ \\
\hline 1997 & $\begin{array}{c}0.144 * * * \\
(0.018)\end{array}$ \\
\hline 1998 & $\begin{array}{c}0.101 * * * \\
(0.023)\end{array}$ \\
\hline 1999 & $\begin{array}{c}0.097 * * * \\
(0.018)\end{array}$ \\
\hline 2000 & $\begin{array}{c}0.084 * * * \\
(0.017)\end{array}$ \\
\hline 2001 & $\begin{array}{c}0.112 * * * \\
(0.012)\end{array}$ \\
\hline 2002 & $\begin{array}{c}0.118 * * * \\
(0.012)\end{array}$ \\
\hline 2003 & $\begin{array}{c}0.080 * * * \\
(0.014)\end{array}$ \\
\hline 2004 & $\begin{array}{l}0.105^{* * * *} \\
(0.014)\end{array}$ \\
\hline 2005 & $\begin{array}{c}0.122 * * * \\
(0.016)\end{array}$ \\
\hline 2006 & $\begin{array}{c}0.147 * * * \\
(0.013)\end{array}$ \\
\hline 2007 & $\begin{array}{c}0.160 * * * \\
(0.014)\end{array}$ \\
\hline 2008 & $\begin{array}{c}0.154 * * * \\
(0.012)\end{array}$ \\
\hline 2009 & $\begin{array}{c}0.146^{* * * *} \\
(0.015)\end{array}$ \\
\hline 2010 & $\begin{array}{c}0.156^{* * * *} \\
(0.014)\end{array}$ \\
\hline 2011 & $\begin{array}{c}0.140 * * * \\
(0.015)\end{array}$ \\
\hline 2012 & $\begin{array}{c}0.150 * * * \\
(0.020)\end{array}$ \\
\hline 2013 & $\begin{array}{c}0.170 * * * \\
(0.019)\end{array}$ \\
\hline 2014 & $\begin{array}{c}0.153 * * * \\
(0.043)\end{array}$ \\
\hline 2015 & $\begin{array}{c}0.112^{* * * *} \\
(0.017)\end{array}$ \\
\hline 2016 & $\begin{array}{c}0.123 * * * \\
(0.016)\end{array}$ \\
\hline 2017 & $\begin{array}{c}0.110 * * * \\
(0.017)\end{array}$ \\
\hline
\end{tabular}

Note: standard errors in parentheses $* * * \mathrm{p}<0.01, * * \mathrm{p}<0.05, * \mathrm{p}<0.1$ Source: Current Population Surveys 
Figure 5: Comparing Wage differentials (OLS vs. Heckman)

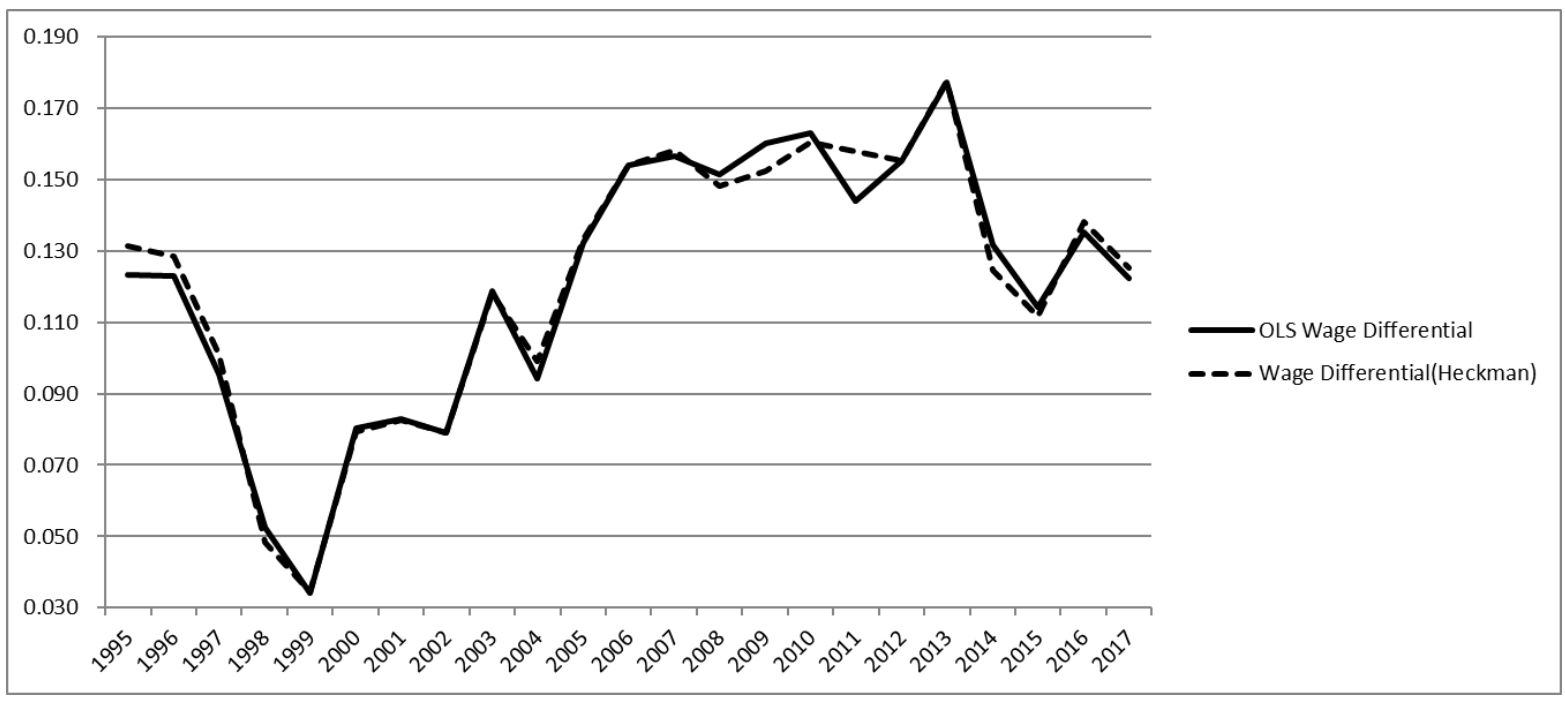

Figure 6: Comparing Wage differentials (OLS vs. Heckman, 4 Occupation)

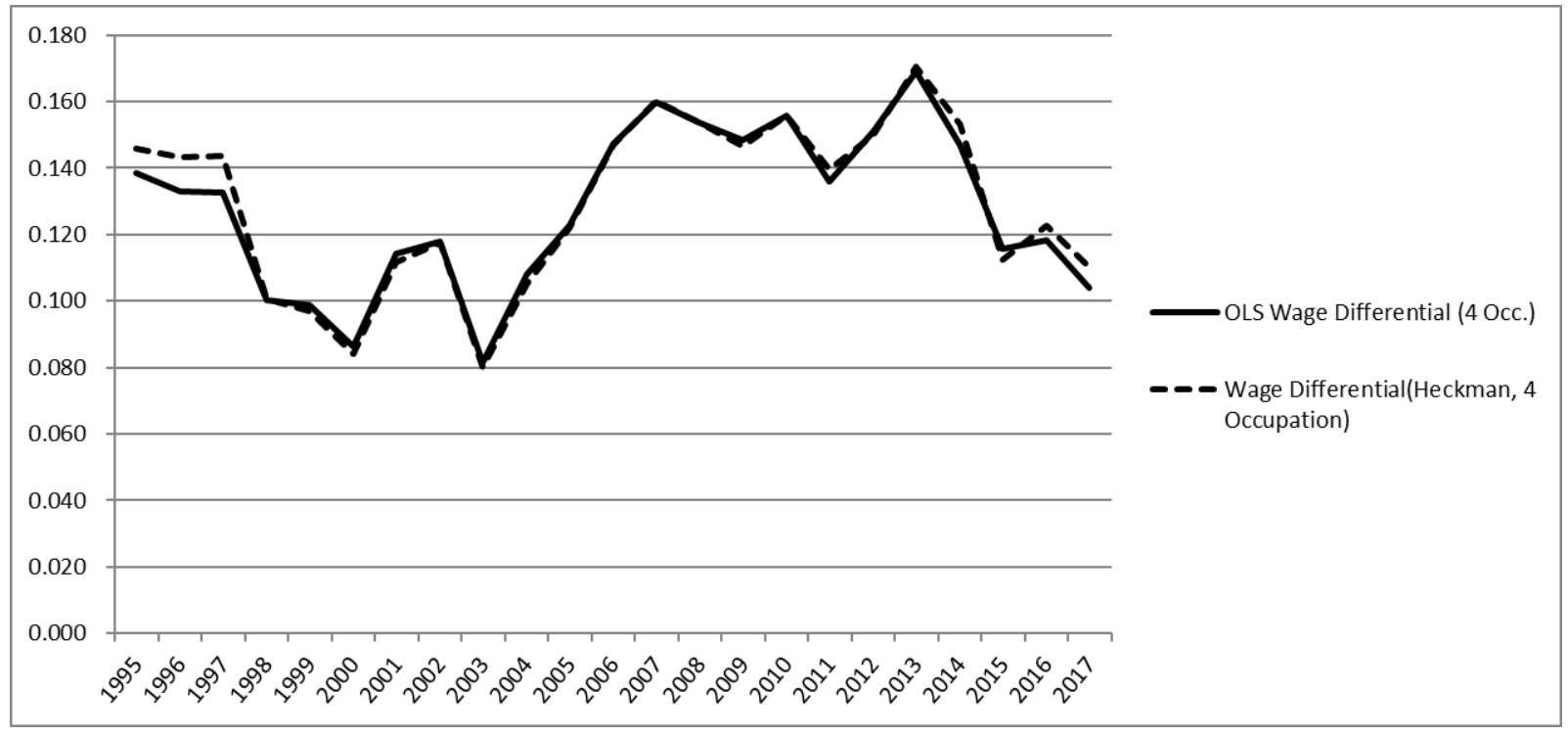

41 
Table 11: Fringe Benefit Differential from Probit model

\begin{tabular}{|c|c|c|}
\hline & Pension Plan & Health Insurance \\
\hline 1995 & $\begin{array}{c}0.252^{* * *} \\
(0.032)\end{array}$ & $\begin{array}{l}0.095^{* * *} \\
(0.023)\end{array}$ \\
\hline 1996 & $\begin{array}{l}0.291^{* * *} \\
(0.034)\end{array}$ & $\begin{array}{l}0.087^{* * *} \\
(0.024)\end{array}$ \\
\hline 1997 & $\begin{array}{l}0.263^{* * *} \\
(0.036)\end{array}$ & $\begin{array}{l}0.029 \\
(0.029)\end{array}$ \\
\hline 1998 & $\begin{array}{l}0.260^{* * *} \\
(0.036)\end{array}$ & $\begin{array}{l}0.058 * * \\
(0.028)\end{array}$ \\
\hline 1999 & $\begin{array}{l}0.214^{* * *} \\
(0.037)\end{array}$ & $\begin{array}{l}0.002 \\
(0.031)\end{array}$ \\
\hline 2000 & $\begin{array}{l}0.134^{* * *} \\
(0.036)\end{array}$ & $\begin{array}{l}-0.003 \\
(0.028)\end{array}$ \\
\hline 2001 & $\begin{array}{l}0.182^{* * *} \\
(0.026)\end{array}$ & $\begin{array}{l}0.064^{* * *} \\
(0.016)\end{array}$ \\
\hline 2002 & $\begin{array}{l}0.193^{* * *} \\
(0.026)\end{array}$ & $\begin{array}{l}0.055^{* * *} \\
(0.017)\end{array}$ \\
\hline 2003 & $\begin{array}{l}0.244^{* * *} \\
(0.025)\end{array}$ & $\begin{array}{l}0.019 \\
(0.019)\end{array}$ \\
\hline 2004 & $\begin{array}{l}0.208^{* * *} \\
(0.026)\end{array}$ & $\begin{array}{l}0.047^{* *} \\
(0.019)\end{array}$ \\
\hline 2005 & $\begin{array}{l}0.250^{* * *} \\
(0.032)\end{array}$ & $\begin{array}{l}0.064^{* * *} \\
(0.024)\end{array}$ \\
\hline 2006 & $\begin{array}{l}0.189^{* * *} \\
(0.032)\end{array}$ & $\begin{array}{l}0.034 \\
(0.026)\end{array}$ \\
\hline 2007 & $\begin{array}{l}0.233^{* * *} \\
(0.032)\end{array}$ & $\begin{array}{l}0.094^{* * *} \\
(0.024)\end{array}$ \\
\hline 2008 & $\begin{array}{l}0.204^{* * *} \\
(0.033)\end{array}$ & $\begin{array}{l}0.041 \\
(0.028)\end{array}$ \\
\hline 2009 & $\begin{array}{l}0.259^{* * * *} \\
(0.032)\end{array}$ & $\begin{array}{l}0.057^{* *} \\
(0.027)\end{array}$ \\
\hline 2010 & $\begin{array}{l}0.262^{* * *} \\
(0.030)\end{array}$ & $\begin{array}{l}0.102^{* * *} \\
(0.024)\end{array}$ \\
\hline 2011 & $\begin{array}{l}0.296^{* * *} \\
(0.031)\end{array}$ & $\begin{array}{l}0.109^{* * *} \\
(0.025)\end{array}$ \\
\hline 2012 & $\begin{array}{l}0.238^{* * *} \\
(0.033)\end{array}$ & $\begin{array}{l}0.062^{* *} \\
(0.028)\end{array}$ \\
\hline 2013 & $\begin{array}{l}0.255^{* * *} \\
(0.032)\end{array}$ & $\begin{array}{l}0.099^{* * *} \\
(0.026)\end{array}$ \\
\hline 2014 & $\begin{array}{l}0.246^{* * *} \\
(0.030)\end{array}$ & $\begin{array}{l}-0.020 \\
(0.029)\end{array}$ \\
\hline 2015 & $\begin{array}{l}0.268^{* * *} \\
(0.032)\end{array}$ & $\begin{array}{l}-0.043 \\
(0.030)\end{array}$ \\
\hline 2016 & $\begin{array}{l}0.224^{* * *} \\
(0.031)\end{array}$ & $\begin{array}{r}0.050^{*} \\
(0.027)\end{array}$ \\
\hline 2017 & $\begin{array}{l}0.222^{* * *} \\
(0.032)\end{array}$ & $\begin{array}{l}-0.036 \\
(0.030)\end{array}$ \\
\hline
\end{tabular}

Note: standard errors in parentheses ${ }^{* * *} \mathrm{p}<0.01,{ }^{* *} \mathrm{p}<0.05,{ }^{*} \mathrm{p}<0.1$

Source: Current Population Surveys 
Figure 7: Trend of Pension Plan Differentials, Year-by-Year, March CPS

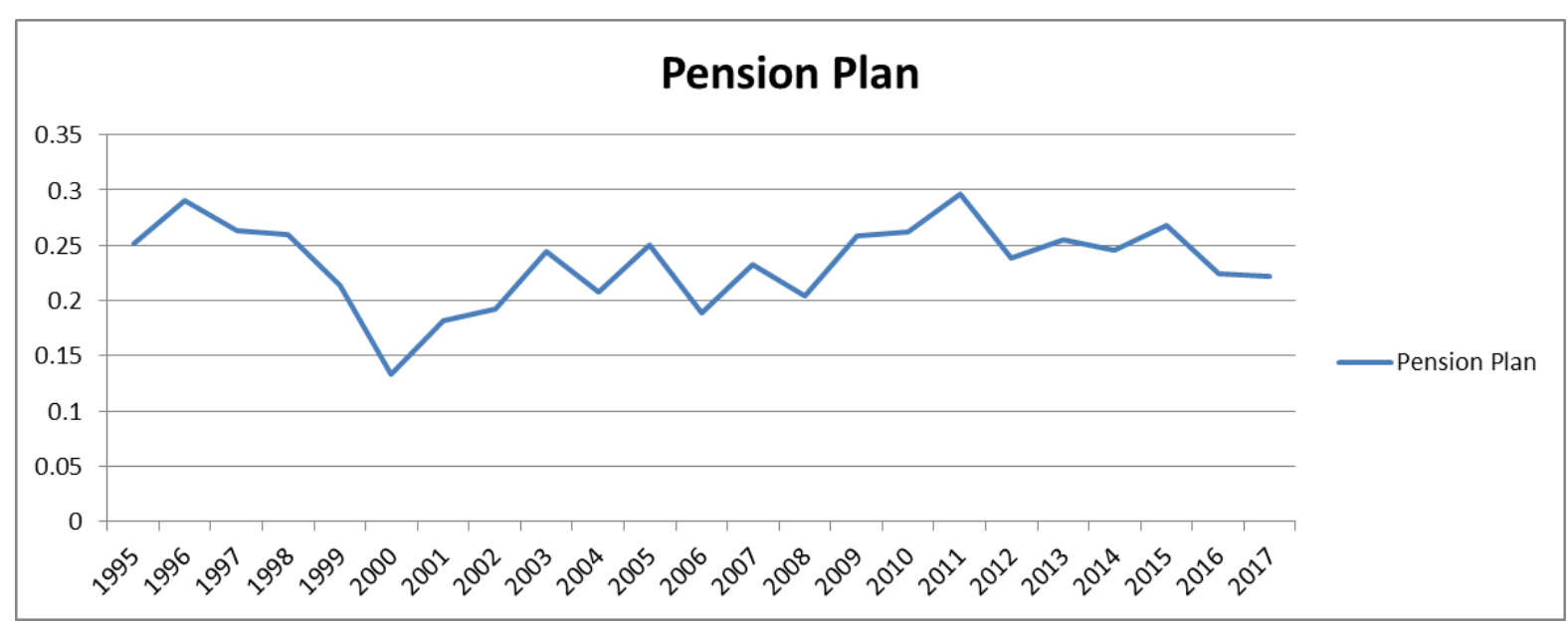

Figure 8: Trend of Health Insurance Differentials, Year-by-Year, March CPS

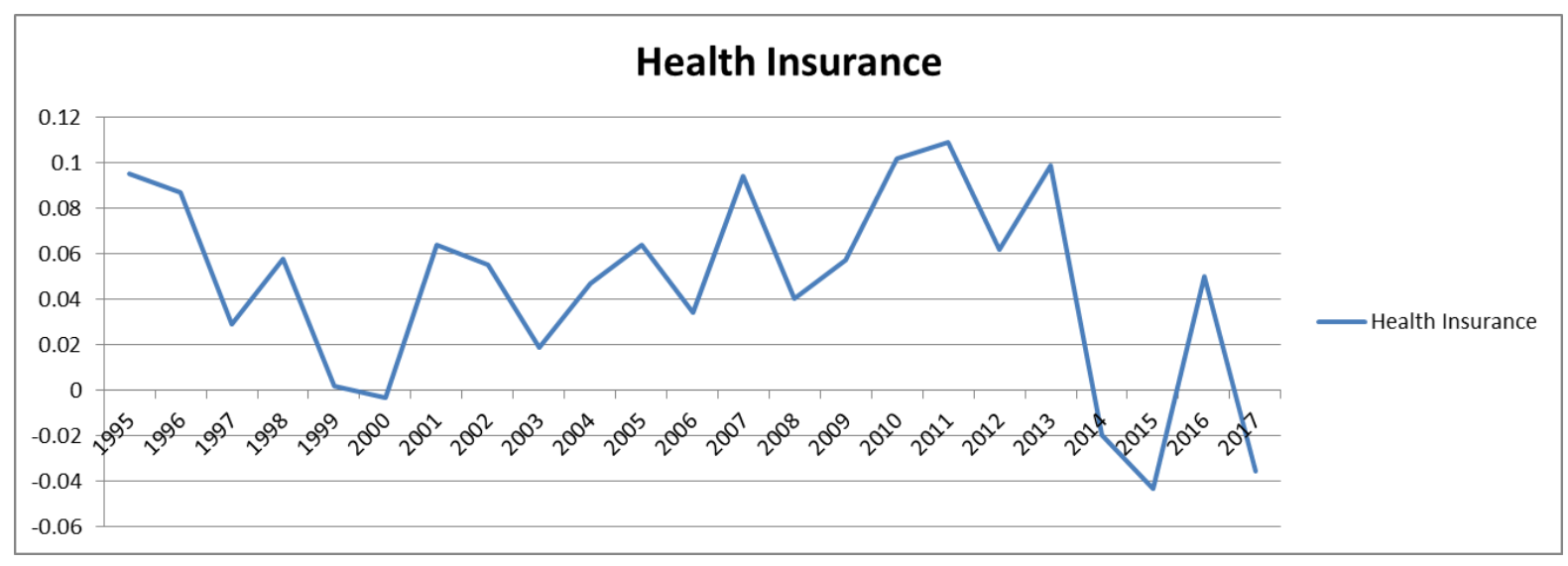

43 
Table 12 : Time series analysis of Wage Differentials

\begin{tabular}{|l|c|c|c|c|}
\hline \multirow{2}{*}{ Unemployment Rate (Age 25 54) } & \multicolumn{2}{|c|}{ Specification 1 } & \multicolumn{2}{c|}{ Specification 2 } \\
\cline { 2 - 5 } & All & 4 Occ. & All & 4 Occ. \\
\cline { 2 - 5 } & Coef. & Coef. & Coef. & Coef. \\
\hline \hline \multirow{3}{*}{ Fed. Spending to GDP } & -0.003 & 0.001 & -0.011 & -0.005 \\
& $(0.006)$ & $(0.006)$ & $(0.008)$ & $(0.009)$ \\
& $0.017^{* * *}$ & 0.007 & $0.025^{* *}$ & 0.013 \\
Obama & $(0.005)$ & $(0.006)$ & $(0.011)$ & $(0.009)$ \\
\multirow{3}{*}{ Trump } & & & $0.034^{* *}$ & 0.005 \\
& & & $(0.014)$ & $(0.013)$ \\
Constant & & & 0.011 & -0.004 \\
& & & $(0.024)$ & $(0.021)$ \\
& & & -0.014 & $-0.036^{*}$ \\
& & & $(0.025)$ & $(0.020)$ \\
& & & $-0.337^{*}$ & -0.109 \\
& $-0.196^{* *}$ & -0.009 & $(0.171)$ & $(0.138)$ \\
\hline
\end{tabular}

Note: Huber/White robust standard errors in parentheses, ${ }^{* * *} \mathrm{p}<0.01,{ }^{* *} \mathrm{p}<0.05,{ }^{*} \mathrm{p}<0.1$ 